\title{
Mechanical Behavior of Two-Leaf Masonry Wall-Strengthening Using Different Grouts
}

\author{
Eduarda Luso, Ph.D. ${ }^{1}$; and Paulo B. Lourenço, Ph.D. ${ }^{2}$
}

\begin{abstract}
Grout injection is an efficient method to improve the mechanical characteristics of masonry walls, in the presence of voids or cracks. Masonry made up of two exterior leaves with the space between them filled with poor infill with a large amount of voids is common in many existing structures. In other cases, dry stack masonry is used. Grouting of these types of vulnerable masonry with lime-based grouts was proven mechanically efficient. The success of this technique depends on several parameters, such as injection pressure, the general condition of the masonry (materials and mechanical properties), and the rheological properties of the grout. The effect of ternary grouts and hydraulic lime-based grouts on the compressive and shear strength of three-leaf stone masonry has been widely investigated. However, fewer studies have been done on walls with one or two leaves, as done in this paper. The present research aims to investigate the mechanical performance of schist masonry walls before and after injection. Six masonry walls of typical schist stone constructions from the north of Portugal were constructed in accordance with the original construction materials and tested under compressive load. Two different grouts were chosen to inject the wall specimens (one commercially available and another prescribed). The results obtained showed that these strengthening techniques were successful in increasing the compressive strength of the walls and improving their behavior under compressive loads. DOI: 10.1061/(ASCE)MT.1943-5533.0002712. (C) 2019 American Society of Civil Engineers.
\end{abstract}

Author keywords: Schist masonry; Grout; Injection; Walls.

\section{Introduction}

Schist constructions are an important cultural, architectural, and historical legacy in Europe, and particularly in Portugal, whose preservation is of importance. There are many buildings of schist masonry spread all over Portugal, varying in terms of building typology, constructive techniques, and even type of schist (Barros et al. 2010). Schist masonry in northeastern Portugal typically has two types of constructions: with mortar joints, usually with mixtures based on clay or lime, or with dry joints, normally used in encircling walls, mills, and shelters (Fig. 1).

Similar to other stone masonry constructions, schist masonry buildings suffer damage due to their weak tensile strength. Therefore, they frequently need stabilization, repair, or strengthening. Cement and lime-based grouting is a well-known intervention technique, which can be durable and mechanically efficient while preserving the historical nature of the structure to a reasonable extent. Parameters such as rheology, injectability, and stability of the grout mix should be considered to ensure the effectiveness of any injection. Grouting is efficient when applied to types of masonry encountering a large percentage of voids, mainly to the frequent type of three-leaf masonry (Vintzileou 2006; Vintzileou and Miltiadou-Fezans 2008). The effectiveness of the injection technique has long been considered for this type of masonry in many research works (Valluzi 2000; Vintzileou 2011; Oliveira et al. 2012;

\footnotetext{
${ }^{1}$ Professor, Dept. of Civil Constructions, Institute for Sustainability and Innovation in Structural Engineering, Polytechnic Institute of Bragança, Campus Sta Apolónia, 5300-253 Bragança, Portugal (corresponding author). ORCID: https://orcid.org/0000-0001-7979-1308. Email: eduarda@ipb.pt

${ }^{2}$ Professor, Dept. of Civil Engineering, ISISE, Univ. of Minho, Azurém, 4800-058 Guimarães, Portugal. Email: pbl@civil.uminho.pt

Note. This manuscript was submitted on February 26, 2018; approved on November 30, 2018; published online on April 23, 2019. Discussion period open until September 23, 2019; separate discussions must be submitted for individual papers. This paper is part of the Journal of Materials in Civil Engineering, (C) ASCE, ISSN 0899-1561.
}

Silva 2008). However, the goal of this study was to precisely understand the behavior of this type of schist walls, in particular after injection. Afterward, the effectiveness of this technique was tested in schist masonry walls, which traditionally have a building typology of one or two leaves because there is no related research in the literature. Six wall specimens with mortared joints were built by an experienced mason accustomed to constructing these walls in real life. The mortar composition was chosen to be representative of old mortar in terms of components, strength, and deformability. Four walls were subsequently injected with two types of lime-based grout. One of the chosen grouts was a ready-mix commercially available grout (Mape-Antique I of Mapei), which was compared with other commercial grouts by Luso and Lourenço (2016). The second grout adopted was a composition formulated in the laboratory (Luso and Lourenço 2017a) with similar results compared to the commercial grout, but not compared in full masonry walls. After an extended laboratory study on the two grouts (Luso and Lourenço 2017b), the behavior of walls injected with these products was evaluated, with the aim of increasing the mechanical strength of the walls and improving their deformability.

\section{Experimental Program}

The experimental research presented in this paper involved the construction, injection, and testing of three sets of schist masonry walls. All the procedures were done in the Laboratory of Structures at the University of Minho in Guimarães, Portugal. A description of the materials and construction method used is given in the next sections.

\section{Stone}

The shale used for the construction of the walls came from Vila Nova de Foz Côa in the north of Portugal. It was directly extracted from the quarry and transported on pallets to Guimarães without 


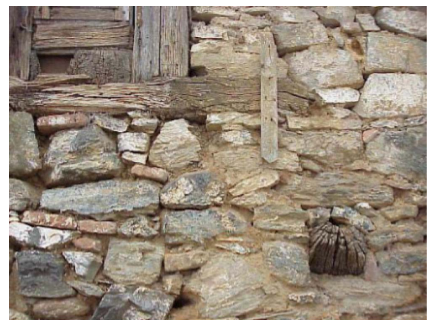

(a)

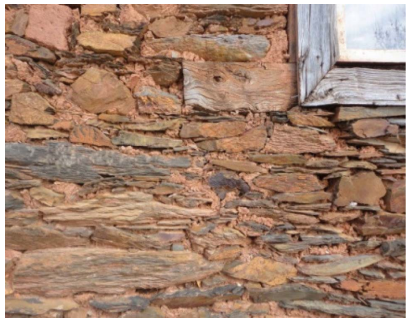

(b)

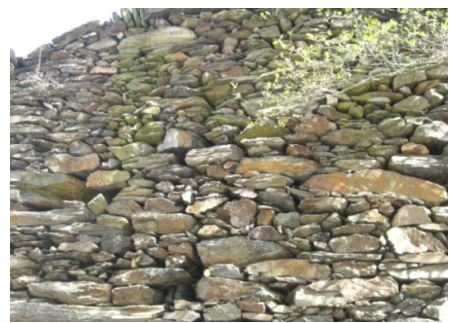

(c)

Fig. 1. Schist masonry walls: (a and b) with mortar joints; (c) with dry joints.
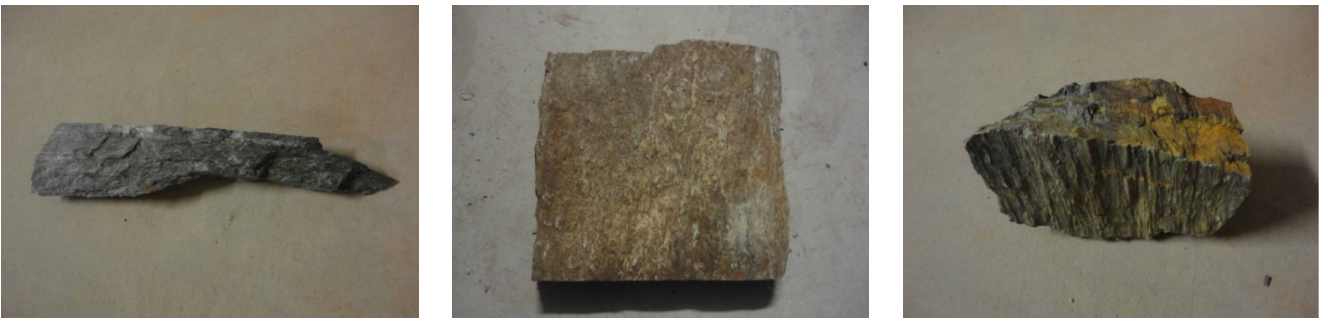

Fig. 2. Appearance of schist stones after cutting with hammer and pointer.

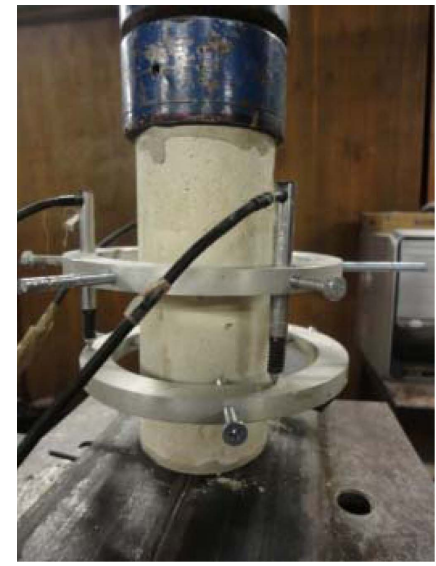

(a)

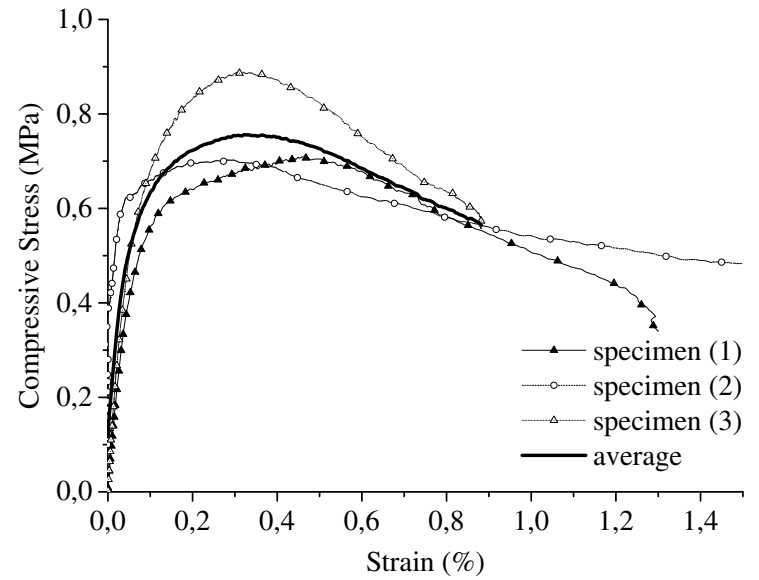

(b)

Fig. 3. (a) Compression test; and (b) stress-strain graph obtained in compression test.

Table 1. Results obtained in mechanical tests. Coefficients of variation in parentheses (\%)

\begin{tabular}{llcccc}
\hline Age & Specimen & $f_{c}(\mathrm{MPa})$ & $E_{30 \%-60 \%}(\mathrm{MPa})$ & $\delta_{\text {peak }}(\%)$ & $G_{f}(\mathrm{~N} / \mathrm{mm})$ \\
\hline 28 days & Prismatic & $0.71(16.9)$ & - & - & - \\
90 days & Prismatic & $0.76(18.2)$ & - & - & - \\
150 days & Prismatic & $0.85(11.9)$ & - & - & - \\
150 days & Cylinder & $0.77(13.8)$ & $679.9(9.1)$ & $0.35(24.9)$ & $1.15(21.4)$ \\
\hline
\end{tabular}

any treatment. A detailed description of this stone can be found in Barros (2013). These stones break easily along their foliation planes (Barros et al. 2014) when applying a stroke with a hammer and, if necessary, with a pointer and a chisel. Then, the pieces were cut according to the required shape for the wall construction, resulting in irregularly shaped stone pieces (Fig. 2). The schist, kept packed on pallets, covered with plastic, and placed outside until the time of wall construction, presented an average moisture 

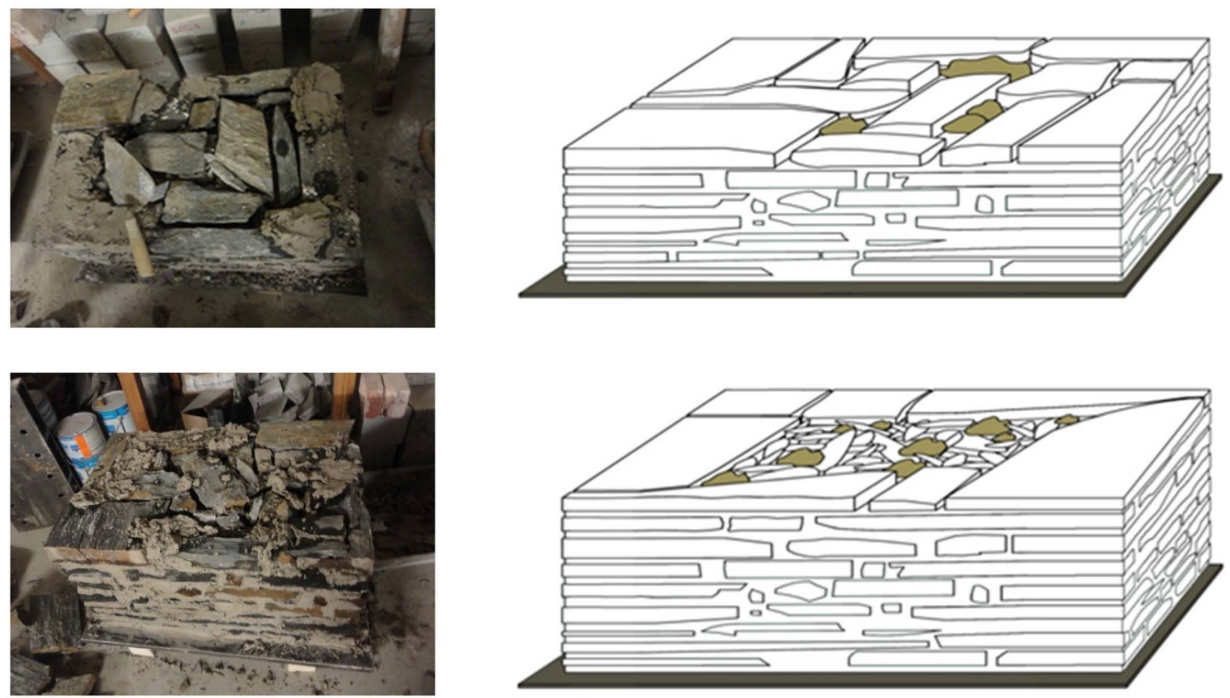

Fig. 4. Construction of the walls.

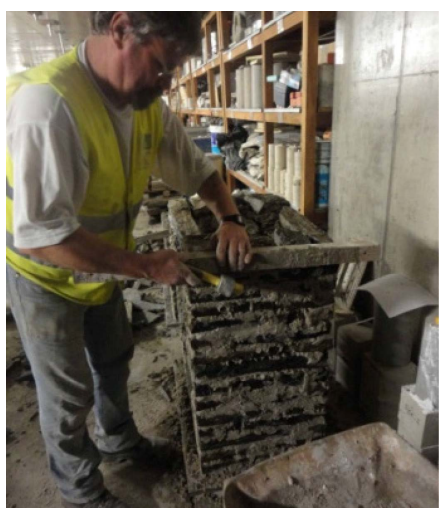

(a)

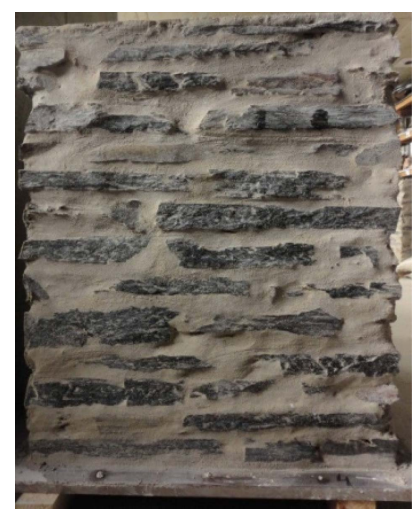

(b)

Fig. 5. (a) Construction of the walls; and (b) final aspect of Wall P4.

content of $0.2 \%$ in a test following the procedure described in EN 1097-5 (CEN 2001).

\section{Mortar}

For the preparation of the mortar, a fine-grained sand from a local supplier was used. As binder, hydrated lime CL90-S, from Lusical, and the natural hydraulic lime NHL5 of Cimpor company were used.

The binder:sand proportion adopted was 1:2, whereas the water: binder ratio was 0.4 (all ratios in weight). The choice of materials used was based on studies conducted by Rodrigues (2004).

The compressive strength of the mortar was assessed on prismatic specimens of $16 \times 4 \times 4 \mathrm{~cm}^{3}$ and cylinders with $7 \mathrm{~cm}$ of diameter and $14.5 \mathrm{~cm}$ of height for the determination of the elastic modulus, sampled during the construction of the wall specimens and following the procedures described in the standards EN 1015-11 (CEN 1999) and ASTM C469 (ASTM 2002), respectively. Similar curing conditions to those of the walls were adopted for the mortar specimens (at an average temperature of $20^{\circ} \mathrm{C}$ and $70 \%$ of relative humidity), which were subsequently tested under compression at ages 28, 90, and 150 days, and for the prismatic specimens. Three prismatic specimens of each age were tested as well for cylinders specimens [Fig. 3(b)].

The average compressive mortar strengths computed for the aforementioned ages were $0.71,0.76$, and $0.85 \mathrm{MPa}$, respectively (see Table 1). At 150 days, compression tests were carried out on both prismatic and cylindrical specimens. In specimens with a cylindrical shape, vertical deformation was measured using three displacement transducers (LVDTs) arranged at $120^{\circ}$ and fixed to the sample [Fig. 3(a)]. The tests were performed under displacement control $(5 \mu \mathrm{m} / \mathrm{s})$. The results are shown in the stress-strain graph for three of the samples tested [Fig. 3(b)]. On average, the mortar had a low compression strength $(<1 \mathrm{MPa})$. The average value of the elastic modulus was also low, which, for this type of mortar, is compatible with masonry wall support. The ratio

Table 2. Main properties of Grouts A and B. Coefficients of variation (\%) in parentheses

\begin{tabular}{|c|c|c|c|c|c|c|c|}
\hline Grout & $\begin{array}{c}\text { Flow time cone } \\
\text { marsh } 1,000 \mathrm{~mL}^{\mathrm{a}, \mathrm{b}} \\
\text { (seconds) } t=0 \mathrm{~min}\end{array}$ & $\begin{array}{c}\text { Flow time cone } \\
\text { marsh } 1,000 \mathrm{~mL}^{\mathrm{a}, \mathrm{b}} \\
\text { (seconds) } t=30 \mathrm{~min}\end{array}$ & $\begin{array}{c}\text { Flow time cone } \\
\text { marsh } 1,000 \mathrm{~mL}^{\mathrm{a}, \mathrm{b}} \\
\text { (seconds) } t=60 \mathrm{~min}\end{array}$ & $\begin{array}{c}\text { Bleeding }{ }^{\mathrm{b}, \mathrm{c}} \\
\text { (in 100-mL graduated } \\
\text { cylinders) }\end{array}$ & $\begin{array}{c}\text { Compressive } \\
\text { strength }^{\mathrm{b}, \mathrm{d}} \text { at } \\
28 \text { days }(\mathrm{MPa})\end{array}$ & $\begin{array}{c}\text { Flexural } \\
\text { strength }^{\text {b,d }} \text { at } \\
28 \text { days }(\mathrm{MPa})\end{array}$ & $\begin{array}{l}\text { Tensile bond } \\
\text { strength }{ }^{\mathrm{e}, \mathrm{f}} \text { at } \\
90 \text { days }(\mathrm{MPa})\end{array}$ \\
\hline$A$ & 79 & 105 & 110 & 0 & $21.4(4.9)$ & $4.1(2.7)$ & $1.26(16.6)$ \\
\hline$B$ & 40 & 42 & 45 & 0 & $21.5(15.2)$ & $3.5(10.8)$ & $0.87(9.5)$ \\
\hline
\end{tabular}

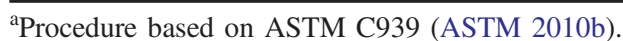

${ }^{\mathrm{b}}$ Mean result of three tests of $160 \times 40 \times 40 \mathrm{~mm}^{3}$ specimens.

${ }^{\mathrm{c}}$ Procedure based on ASTM C940 (ASTM 2010a).

${ }^{\mathrm{d}}$ Procedure based on EN 196-1 (CEN 2016).

${ }^{\mathrm{e}}$ No specific standard.

${ }^{\mathrm{f}}$ Mean result of six tests in yellow granite substrate. 


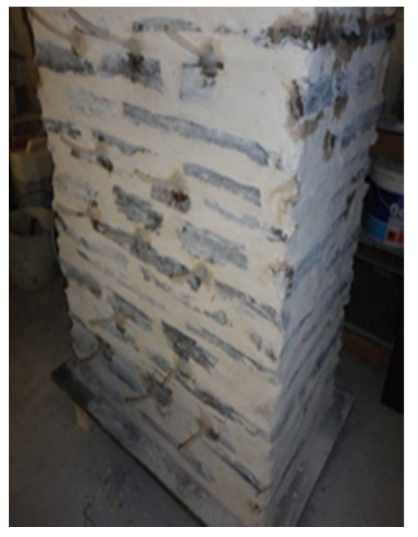

(a)

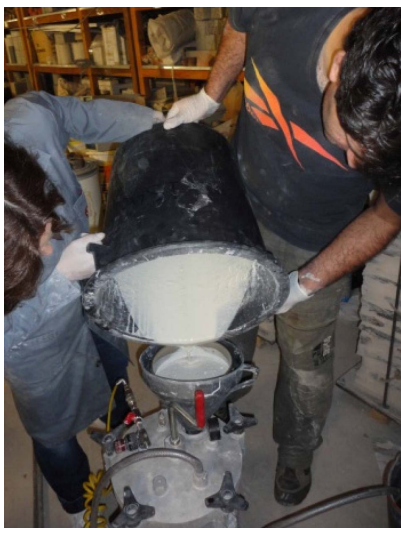

(b)

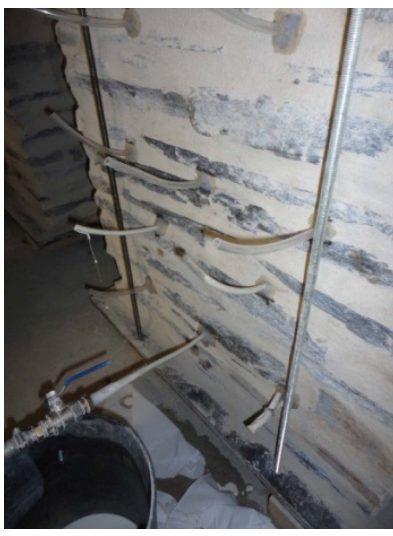

(c)

Fig. 6. (a) Wallet final aspect before grouting; (b) introduction of grout in the pressure pot; and (c) injection of the walls.
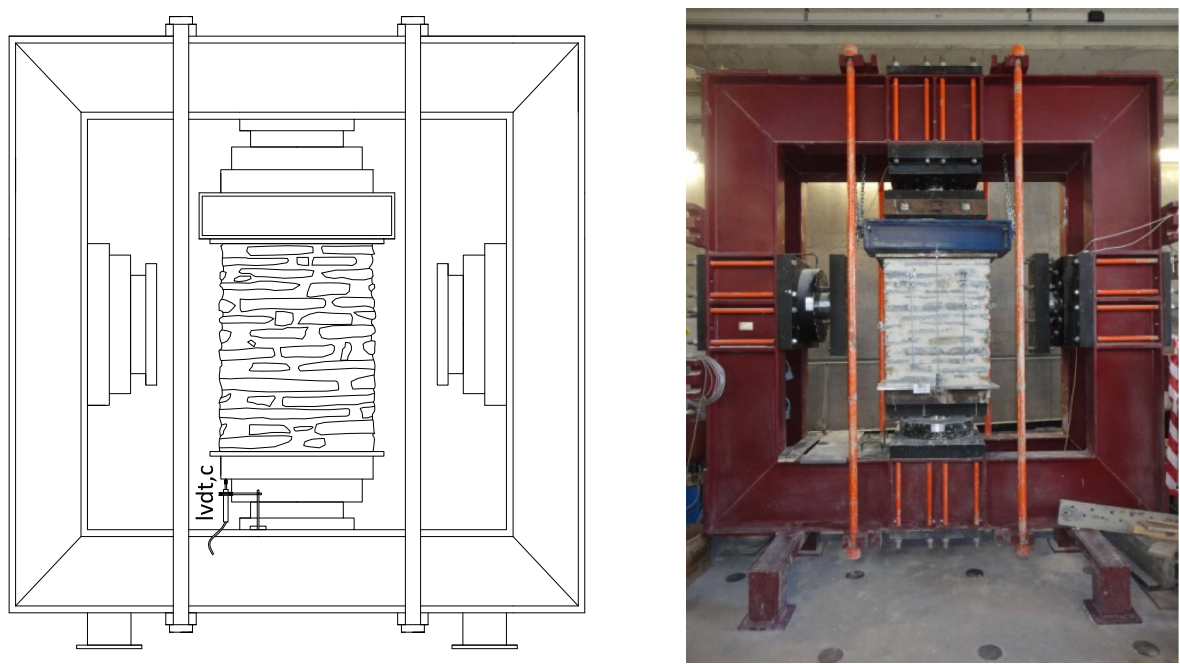

Fig. 7. Test setup of the walls: scheme and testing machine.

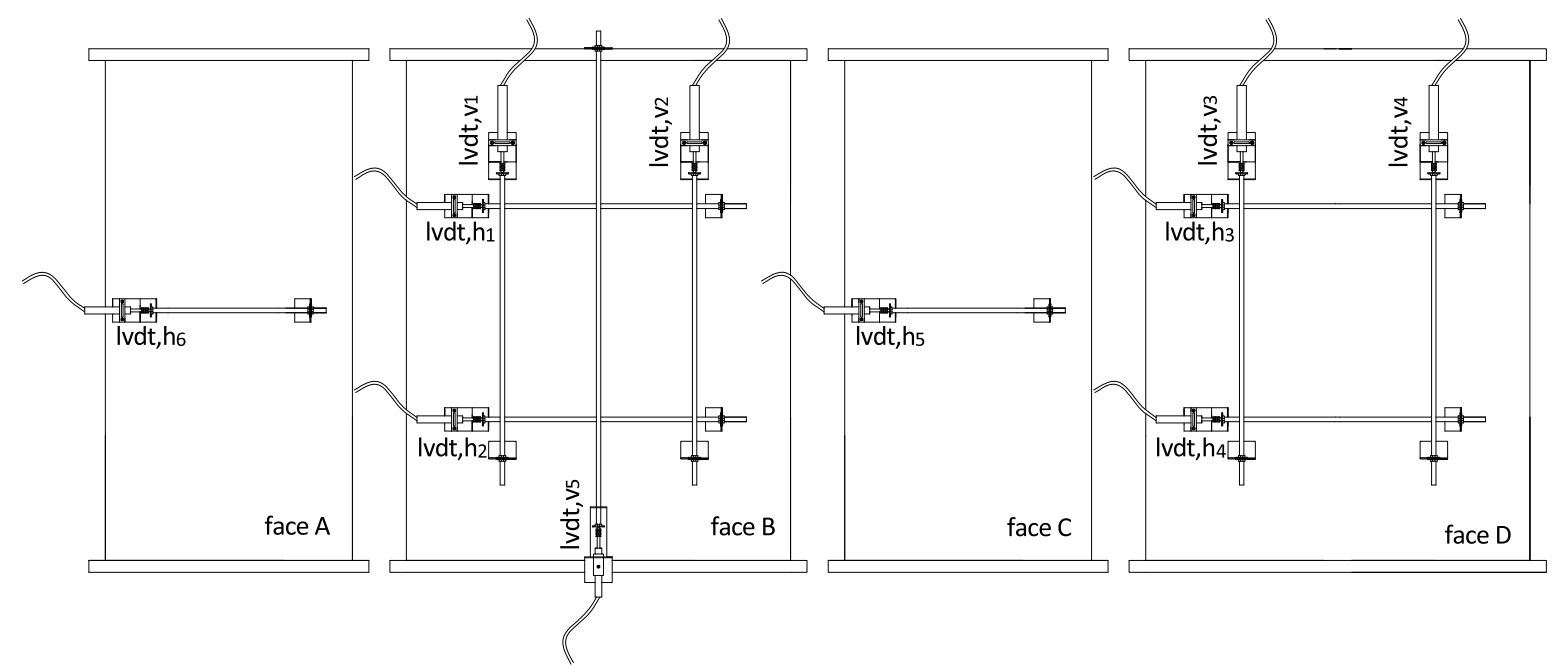

Fig. 8. Test setup of the walls: location of the displacement transducers (Faces a, b, c, and d are, respectively, left, front, right, and back with respect to Fig. 7). 
between the elastic modulus and compressive strength was 880 , which compares well with the value defined in EN 1996-1-1 (CEN 2005) for masonry. The deformation properties in the inelastic range presented a much higher variability than the compressive strength and elastic modulus.

\section{Wall Geometry and Construction}

Six walls in schist masonry were built in the Structures Laboratory of the University of Minho by the same experienced team of masons. The most common schist masonry typology (two leaves) was reproduced using traditional building techniques. The number of specimens was limited due to the size of the walls and space available in the laboratory for the storage of the walls for the necessary period of curing and testing, so only two replicas were built for each specimen type.

The construction of the schist walls in the laboratory took about 6 days, on average one wall per day. The walls were constructed on a stiff steel base, overlaying stone pieces with different sizes and with a coursed arrangement, given the weak resistance schist has in the stratification direction. A scheme and image of the wall construction are shown in Figs. 4 and 5(a). The overlap of the corners and connection between leaves were duly considered, with the placement of stones in the perpendicular direction in each layer, with mortar and gravel or small schist pieces. A void volume within the masonry was ensured to allow the grouting process and, in addition, represent a typical schist masonry wall. An identical stiff steel plate of the base was placed on top after completion of construction to slightly precompress the walls along the vertical direction in order to simulate real conditions and minimize any possible damage caused by drilling or injection pressure.

The wall specimens were $0.70 \mathrm{~m}$ wide, $0.89 \mathrm{~m}$ high, and $0.45 \mathrm{~m}$ thick. The final aspect of one of the walls can be seen in Fig. 5(b). For details on the construction sequence, height of courses, average thickness of horizontal joints, and geometrical details of the walls, see Luso (2012). The walls remained in place after construction for 10 weeks' curing, and then the grouting work began.

\section{Hydraulic Grouts}

Many commercial ready-mix grouts are available on the market and have been frequently prescribed by designers or proposed by specialized contractors. The behavior of four commercial grouts under laboratory conditions was recently evaluated (Luso and Lourenço 2016). However, the use of cement-based and lime-based grouts formulated in the laboratory with the addition of other materials such as fly ashes, silica fume, bentonite, and hydraulic lime, among others, has been proposed by different researchers (Binda et al. 1992; Perret 2002; Toumbakari 2002; Miltiadou-Fezans et al. 2006; Vintzileou 2006; Kalagri et al. 2010; Papayianni and Pachta 2015). The use of calcined clay, in the form of metakaolin, as a pozzolanic material for mortars and concretes has received considerable attention in recent years and also constitutes a good option (SepulcreAguilar and Hernández-Olivares 2010; Brooks and Johari 2001; Melo and Carneiro 2010; Billong et al. 2009; Cachim et al. 2010; Lee et al. 2005; Gleize et al. 2007).

A composition with metakaolin, white cement, and hydrated lime, mixed with a plasticizer, showed satisfactory mechanical and physical properties, which is a viable alternative to the commercial grouts available, either due to cost, availability, or technical considerations (Luso and Lourenço 2017b). Therefore, two grouts were chosen for the injection of the walls: Grout A is a hydraulic grout developed by Mapei, Italy, for historical masonry (MapeAntique I), described in the technical data sheet as a "super-fluid, salt resistance, fillerized hydraulic binder, based on lime and ecopozzolan, for making injection slurries for consolidation masonry"; Grout B is a hydraulic grout prescribed with $30 \%$ white cement CEM II B/L-32,5R from Secil, Portugal; 30\% of hydrated lime type CL90 from Baptistas, Portugal; 35\% of metakaolin Optipozz-sc; water/binder ratio equal to 0.6 ; and superplasticizer (Dynamon SR1 from Mapei). Table 2 shows some of the main properties obtained for the grouts (Luso and Lourenço 2016, 2017b).

\section{Preparation of Walls for Grout Injection}

The walls were prepared for grouting followed well-established procedures (Miltiadou-Fezans et al. 2005; Silva 2008; Biçer-Simsir and Rainer 2011). A series of injection holes were drilled on one

Table 3. Results obtained in compression tests for noninjected masonry walls

\begin{tabular}{lcccccc}
\hline Wall & $\begin{array}{c}f_{c, w} \\
(\mathrm{MPa})\end{array}$ & $\begin{array}{c}\varepsilon_{v, p} \\
(\%)\end{array}$ & $\begin{array}{c}\varepsilon_{h, p} \\
(\%)\end{array}$ & $\begin{array}{c}E_{0} \\
(\mathrm{MPa})\end{array}$ & $\begin{array}{c}E_{30-60} \\
(\mathrm{MPa})\end{array}$ & $\nu_{30-60}$ \\
\hline P4 nI & 1.34 & 0.80 & 0.24 & 513.3 & 296.9 & 0.15 \\
P5 nI & 1.39 & 1.17 & 0.64 & 467.3 & 263.0 & 0.21 \\
Average & 1.37 & 0.98 & 0.44 & 490.3 & 280.0 & 0.18 \\
\hline
\end{tabular}
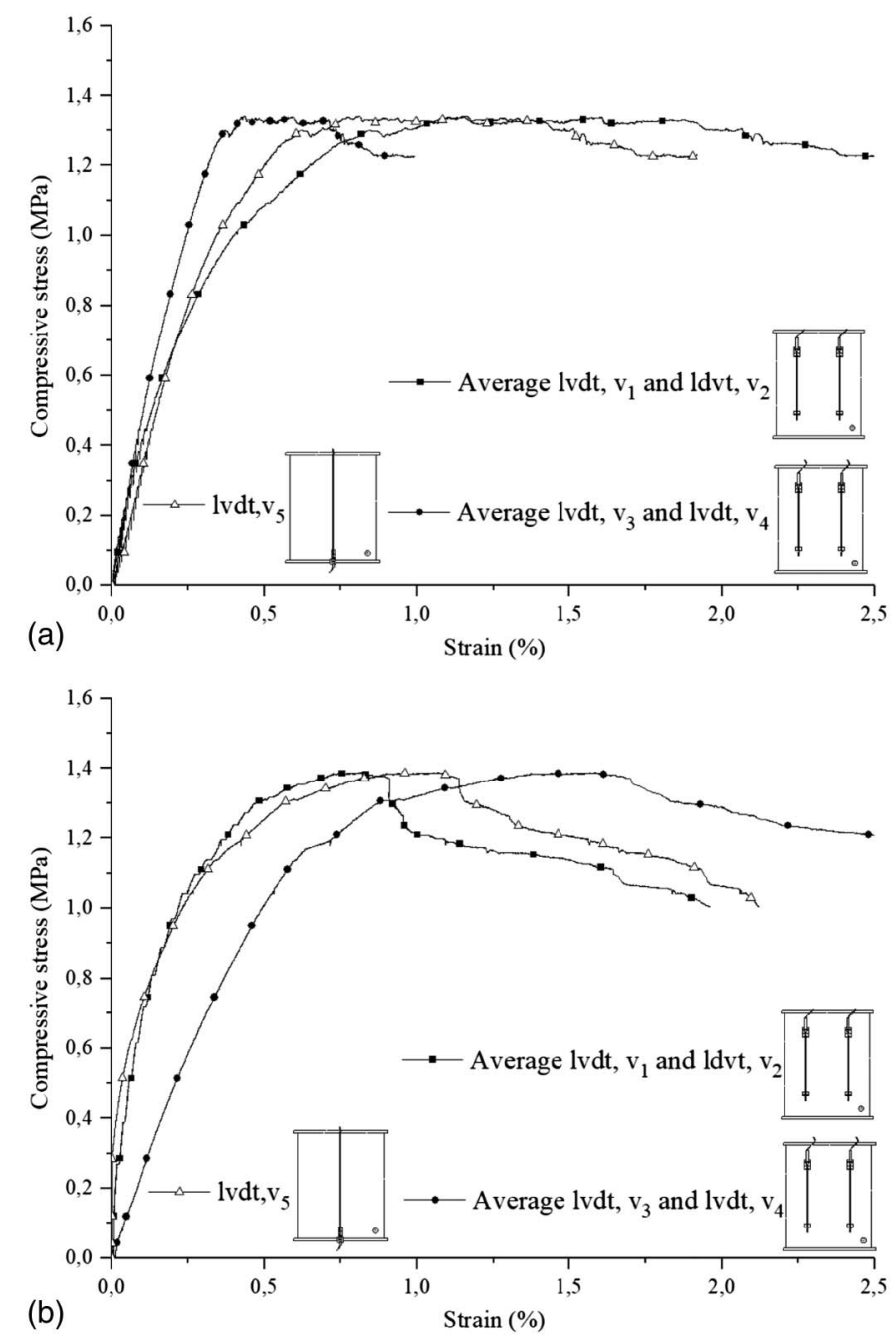

Fig. 9. Relation between compressive stress-vertical extension in (a) P4 nI; and (b) P5 nI. 
side, slightly inclined downward and with a depth of $20-25 \mathrm{~cm}$, following a scheme approximately of equilateral triangles. Into each hole, plastic tubes with $8 \mathrm{~mm}$ diameter were introduced and sealed with silicone. All tubes were numbered for better control of the injection process. The day before the injection process, water was injected in order to wet the interior of each wall and avoid excessive water absorption during grouting.

\section{Grout Injection}

Once the walls were prepared, the grout was introduced at low pressure (around 1.5 bar) in the interior using a pressure pot, starting from the bottom up to the top of the wall.

The grouts were mixed using a mechanical device of low turbulence for about $10 \mathrm{~min}$. Each type of grout was injected into two walls (P2 and P6 with Grout A, P1 and P3 with Grout B) (Fig. 6). Hereafter, the walls are designated as P4 nI and P5 nI for the walls not injected, P2 IA and P6 IA for the walls injected with Grout A, and finally P1 IB and P3 IB for the walls injected with Grout B. During the injection procedure, the active and inactive holes were identified, as well as the volume of grout introduced, the appearance or lack thereof of cracks, and the quantity of grout lost in leaks. On average, 50 and $42.5 \mathrm{dm}^{3}$ of Grouts A and B, respectively, were injected per wall (grout leakage was negligible), corresponding to a volume of $12 \%$, on average, of the total volume specified for the walls. Additional details on the procedure can be found in Luso (2012).

\section{Testing Setup and Measurements}

All wall specimens were tested under monotonic compression using a 2-MN closed-loop servo-controlled testing machine (Fig. 7). The tests were performed under displacement control at a constant

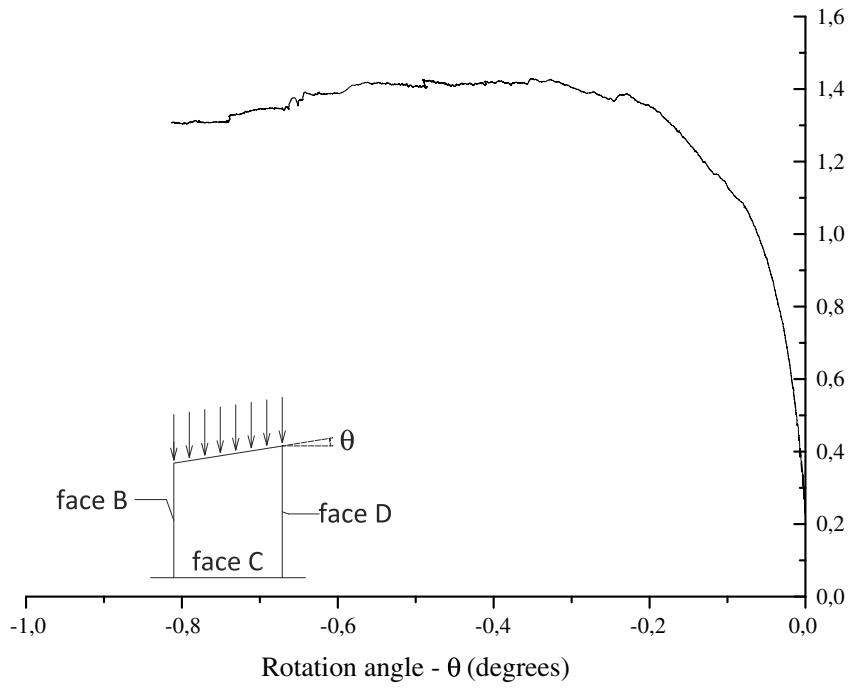

(a)

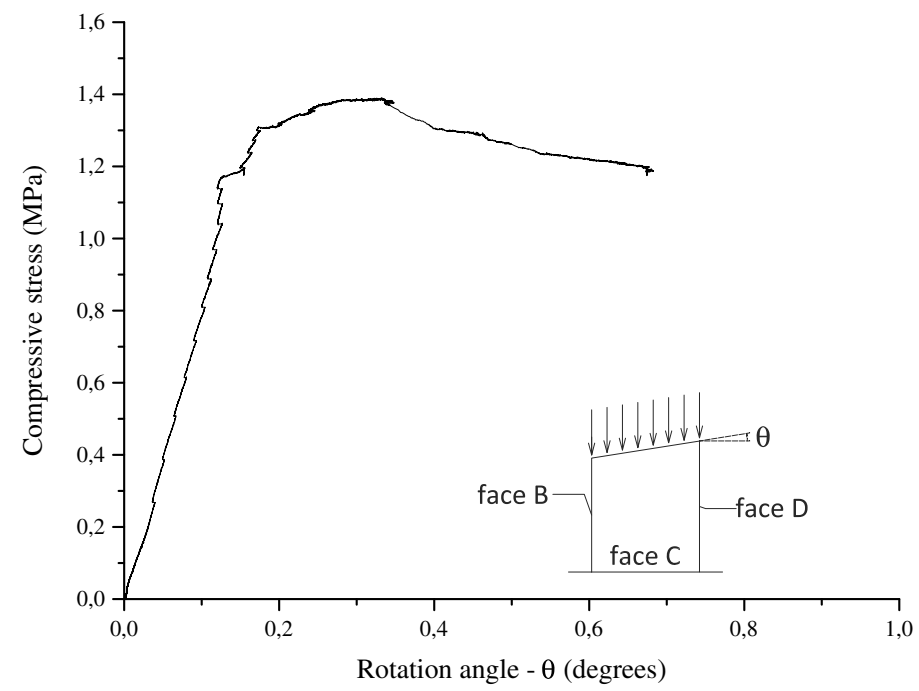

(b)

Fig. 10. Compressive stress versus angle of rotation of the walls: (a) P4 nI; and (b) P5 nI.
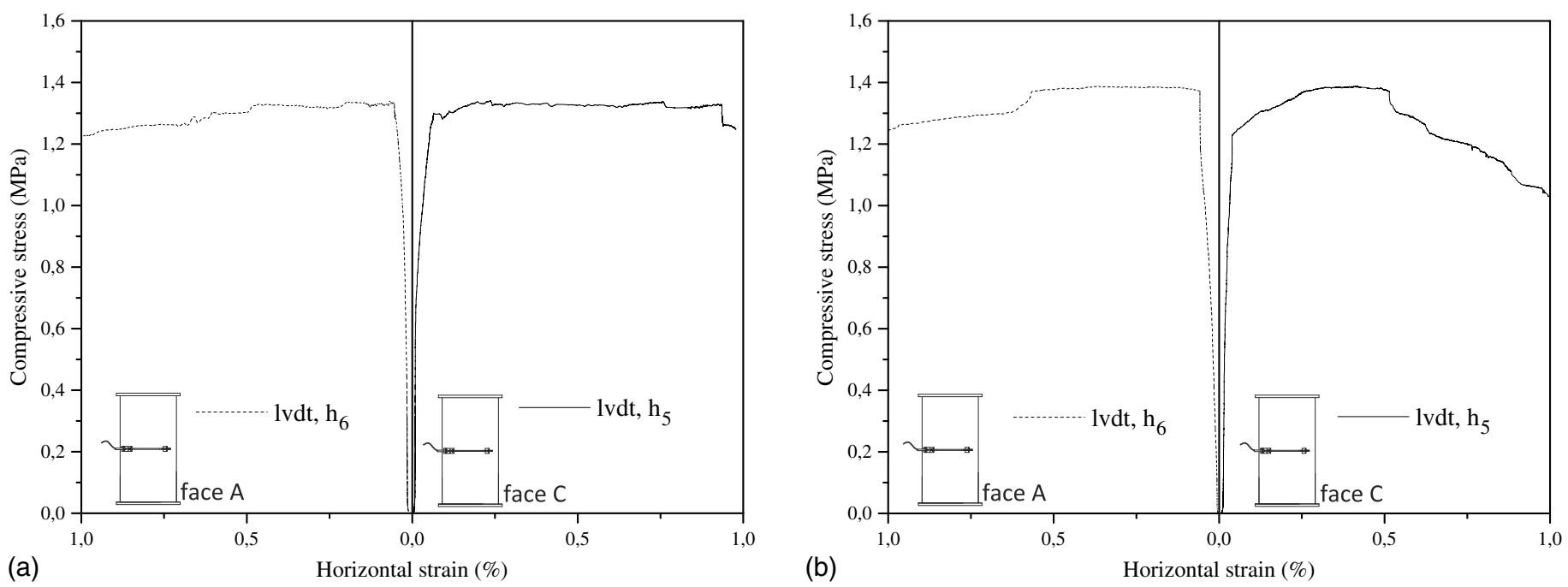

Fig. 11. Compressive stress-horizontal strain graphs on Faces A and C: (a) P4 nI; and (b) P5 nI. 

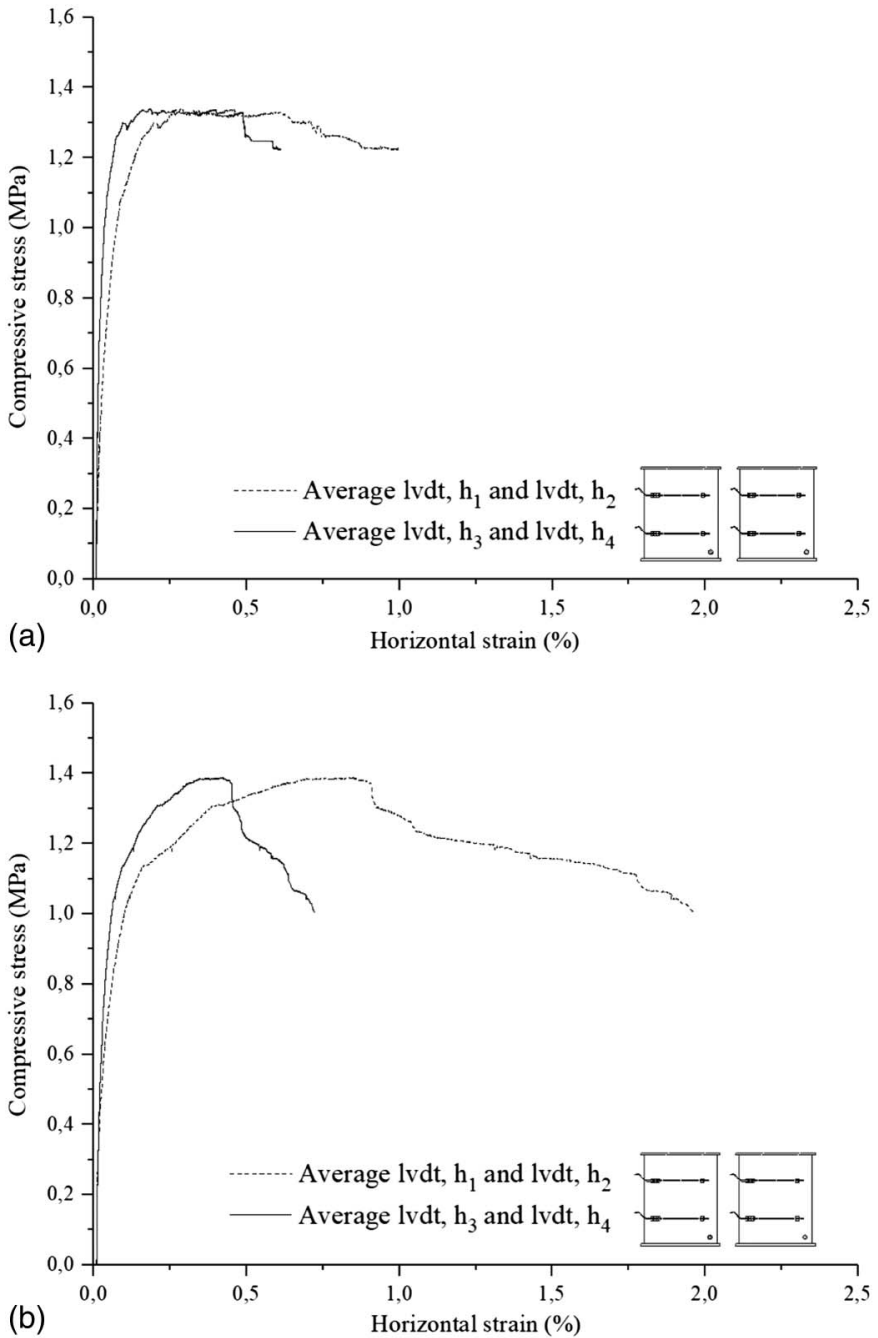

Fig. 12. Compressive stress-horizontal strain graphs on Faces B and D: (a) P4 nI; and (b) P5 nI.

rate of $5 \mu \mathrm{m} / \mathrm{s}$. During the tests, the displacements in the walls were measured by means of linear variable displacement transducers (LVDTs) disposed according to Fig. 8. The LVDT layout in the walls aimed at measuring vertical, horizontal, and transversal displacements directly on the walls in order to compute mechanical parameters. One external LVDT (LVDT v5) was used to measure the displacement between the plates of the testing machine and to control the tests.

In the case of the walls strengthened by injection (P1, P2, P3, and P6), the external leaves were carefully dismantled after testing in order to check the quality of the strengthening procedure.

\section{Results and Discussion}

\section{Experimental Results for Noninjected Masonry Walls $P 4 \mathrm{nl}$ and P5 $\mathrm{nl}$}

Table 3 summarizes the results of the compressive tests carried out on the two unstrengthened walls P4 nI and P5 nI in terms of compressive strength $\left(f_{c, w}\right)$, vertical strain $\left(\varepsilon_{v, p}\right)$, and horizontal strain $\left(\varepsilon_{h, p}\right)$ at peak load, Young's modulus computed in the $0 \%-20 \%$ $\left(E_{0}\right)$ and $30 \%-60 \%$ stress ranges $\left(E_{30-60}\right)$, and Poisson's ratio in the $30 \%-60 \%$ stress range $\left(\nu_{30-60}\right)$.

Taking into account the heterogeneity presented by the masonry of the tested walls, due to the dimensions and irregular geometry of the stones, as well as the variable number and thickness of joints, a high dispersion of the results would be expected. However, there were only significant differences between the two walls for the strains $\varepsilon_{v, p}$ and especially for $\varepsilon_{h, p}$, whereas for the rest of the parameters, similar results were found.

In Fig. 9, a good approximation between the displacements verified in the internal (average of values obtained in LVDTs v1 and v2; see Fig. 7) and external (LVDT v5) schemes can be seen in Face B for walls P4 nI and P5 nI. There was some difference between measurements on Faces B and D, as usual in this type of test due to inevitable rotation, or nonsymmetric failure, of the specimen in the postpeak regimen. Fig. 10 shows the variation of the angle of rotation with the stress level installed.

In relation to the horizontal deformation recorded on the transverse Faces A and C (Fig. 11), values of the same order of magnitude were observed in both walls (Faces B and D) (Fig. 12) because the number of joints in the measuring field was identical (at most, one or two joints between the LVDTs). The graphs of Fig. 11 show that transverse deformation occurred fundamentally and abruptly at load values close to the peak load and increased significantly after rupture. These results are similar to most failures of single-leaf masonry walls, which occur in the transverse direction.

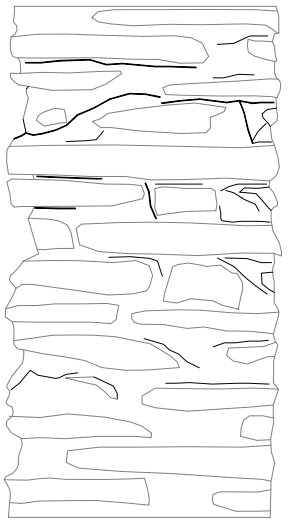

Face A

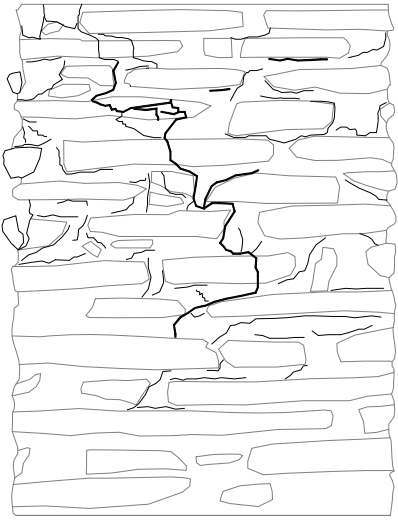

Face B

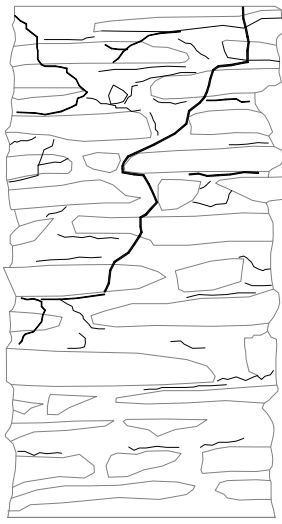

Face C

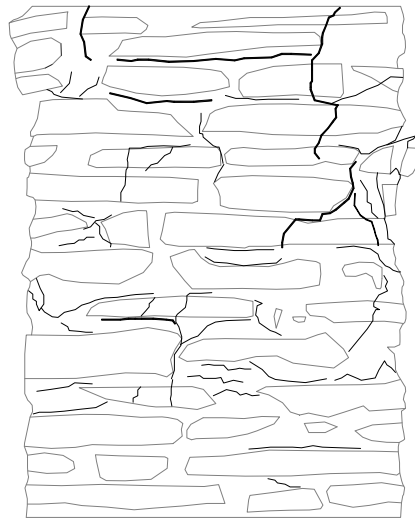

Face D

Fig. 13. Wall cracking pattern in $\mathrm{P} 4 \mathrm{nI}$ at the end of the test. 


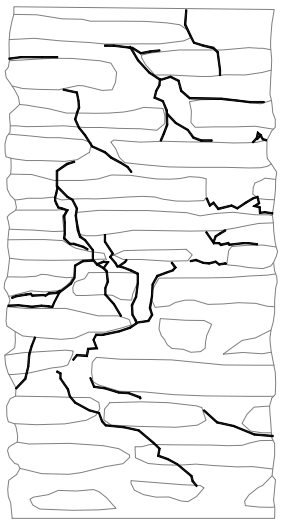

Face A

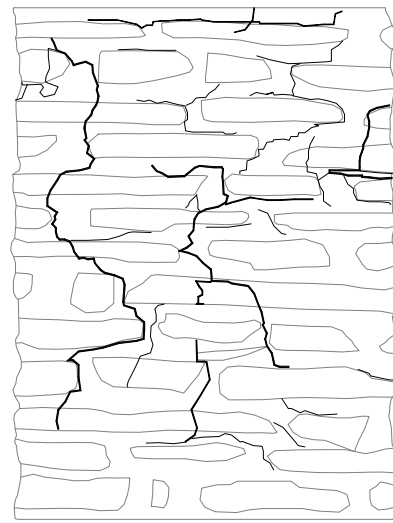

Face B

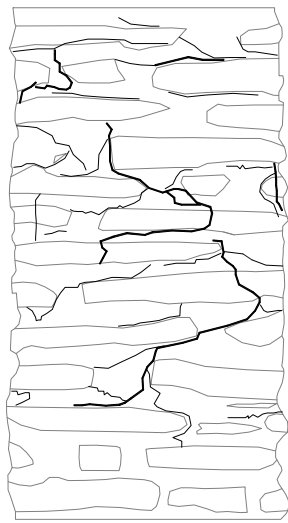

Face C

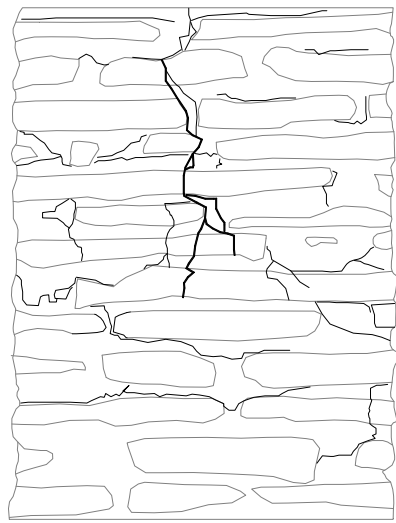

Face D

Fig. 14. Wall cracking pattern in $\mathrm{P} 5 \mathrm{nI}$ at the end of the test.

The cracking pattern of walls P4 nI and P5 nI at the end of the test is shown in Figs. 13 and 14. Up to an axial stress level of 50\% of $f_{c, w}$ in Faces $\mathrm{B}$ and $\mathrm{D}$ and Faces $\mathrm{A}$ and $\mathrm{C}$, only a small number of cracks of predominantly horizontal orientation was observed, resulting from the crushing of the mortar joint, and small cracks were also observed at a $45^{\circ}$ angle between joints. For values close to the maximum load, the cracking pattern had a vertical predominance marked by the breaking of the stone elements. There was also a predominance of those slits in the upper part of the wall. This phenomenon can be seen in the graphs of Fig. 15, which relate the horizontal extension of the walls recorded in the horizontal transducers placed on Faces $\mathrm{B}$ and $\mathrm{C}$ to the height of the wall. It can be seen that the transducers placed in the upper zone of the wall measure larger extensions than those placed in the lower zone, possibly due to the execution of the walls. It is also possible to verify in these graphs that, until a level of axial tension near $50 \%$ of the breaking load, the deformation is negligible. At the end of the test, the width of the cracks varied, with larger cracks reaching values of 5 or $6 \mathrm{~mm}$. In the case of Wall P4 nI between Faces A and C, a localized outward detachment of its elements was observed; see Fig. 16(a). The appearance of the interior of the noninjected walls during the dismantling can be seen in Figs. 16(b and c).

\section{Experimental Results for Injected Masonry Walls}

The results concerning injected walls P1, P2, P3, and P6 are summarized in Tables 4 and 5 . The parameters were determined from the analysis of the results obtained in the uniaxial compression tests. The average value of the compressive strength obtained was about three times higher than the average value obtained for the nonreinforced walls, for both Grouts A and B.

The obtained elastic moduli $\left(E_{0}\right.$ and $\left.E_{30-60}\right)$ also had values, on average, higher than those obtained for nonreinforced walls. In addition, the value of the modulus of elasticity $E_{0}$ was also greater than that of $E_{30-60}$. Among the reinforced walls, P1 IB and P3 IB presented similar values for the modulus of elasticity and compressive strength. The walls reinforced with Grout A presented a high dispersion both for the modulus of elasticity and tensile strength. This is due to the differences in the walls, in particular the different thicknesses and quantities of joints, the number of stone courses, and the high irregularity of the masonry, among others. In the injection of these two walls, there was a significant difference in the quantity of injected grout (42 liters in P6 and 23 liters in P2), which indicates a larger volume of voids in Wall P6,
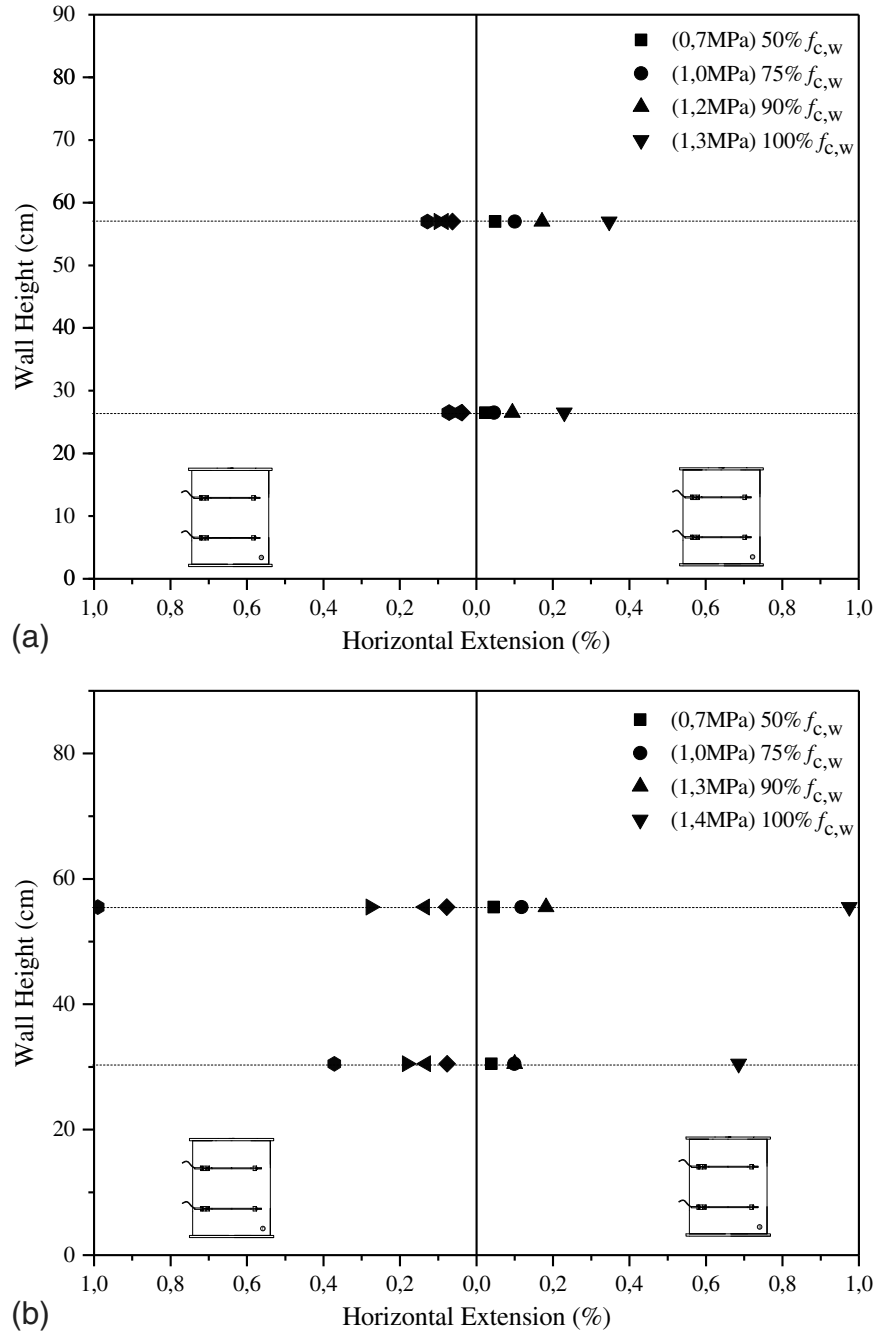

Fig. 15. Variation of the horizontal extension with the load variation and wall height: (a) P4 nI; and (b) P5 nI.

so it is likely that the quantity of stone in Wall P2 was quite higher than that in P6.

In the stress-vertical strain graphs of Fig. 17, it can be verified that there is no significant difference between the vertical 


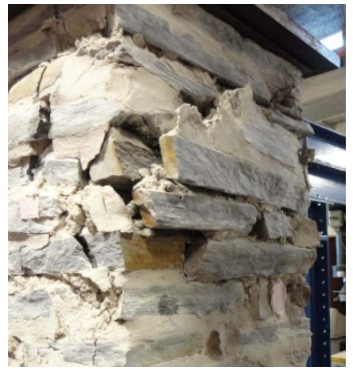

(a)

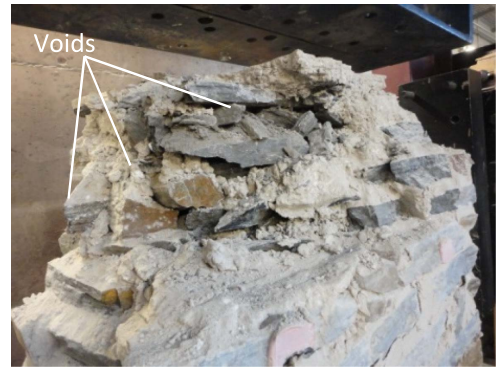

(b)

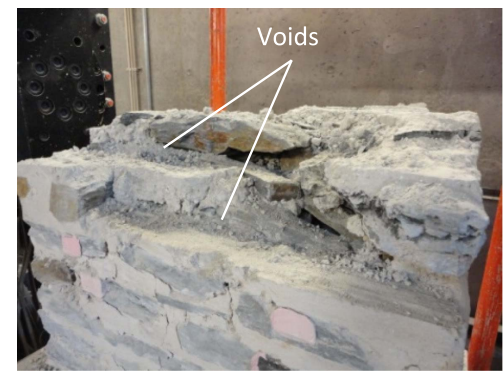

(c)

Fig. 16. (a) Detail of the detachment of stones on Face A on Wall P4 nI; (b) aspect of the interior of Wall P4 nI during disassembly; and (c) appearance of the interior of Wall P5 $\mathrm{nI}$ during disassembly.

Table 4. Summary of test results on walls injected with Grout A

\begin{tabular}{lcccrrr}
\hline Wall & $\begin{array}{c}f_{c, w} \\
(\mathrm{MPa})\end{array}$ & $\begin{array}{c}\varepsilon_{\mathrm{a}, \mathrm{p}} \\
(\%)\end{array}$ & $\begin{array}{l}\varepsilon_{\mathrm{h}, \mathrm{p}} \\
(\%)\end{array}$ & $\begin{array}{c}E_{0} \\
(\mathrm{MPa})\end{array}$ & \multicolumn{1}{c}{$\begin{array}{c}E_{30-60} \\
(\mathrm{MPa})\end{array}$} & $\nu_{30-60}$ \\
\hline P2 IA & 4.5 & 0.56 & 0.09 & $4,272.0$ & $2,500.0$ & 0.01 \\
P6 IA & 3.4 & 1.48 & 0.42 & 980.2 & 533.3 & 0.13 \\
Average & 4.0 & 1.02 & 0.26 & $2,626.1$ & $1,516.5$ & 0.07 \\
\hline
\end{tabular}

Table 5. Summary of test results on walls injected with Grout B

\begin{tabular}{lccccrc}
\hline Wall & $\begin{array}{c}f_{c, w} \\
(\mathrm{MPa})\end{array}$ & $\begin{array}{c}\varepsilon_{a, p} \\
(\%)\end{array}$ & $\begin{array}{c}\varepsilon_{h, p} \\
(\%)\end{array}$ & $\begin{array}{c}E_{0} \\
(\mathrm{MPa})\end{array}$ & $\begin{array}{r}E_{30-60} \\
(\mathrm{MPa})\end{array}$ & $\nu_{30-60}$ \\
\hline P1 IB & 4.4 & 1.08 & 0.48 & $1,978.5$ & 597.0 & 0.20 \\
P3 IB & 4.1 & 0.68 & 0.42 & $2,661.1$ & $1,053.0$ & 0.10 \\
Average & 4.3 & 0.88 & 0.45 & $2,319.8$ & 825.0 & 0.15 \\
\hline
\end{tabular}

displacements in the internal scheme (average of values obtained in LVDTs v1 and v2) and in the external scheme (LVDT v5) in Face B for walls P1 IB and P6 IA. However, in walls P3 IB and P2 IA, there was some difference (Fig. 18). In these two walls, the curvature of the graph at the initial phase of the test showed a more pronounced concavity associated with some adjustment of the steel plates to the test wall specimen. Comparing the measurements on Faces B and D with respect to the vertical deformation, an increase in wall rotation from about $60 \%$ of the maximum load was observed on Wall P3 IB. The evolution of the rotation of the strengthened walls with the applied stress level can be seen in Figs. 19 and 20 .

Regarding the horizontal deformation, the deformations of the transverse Faces A and C (Figs. 21 and 22) were similar to those of Faces B and D (Figs. 23 and 24).

The cracking pattern of walls P1 IB and P3 IB is shown in Figs. 25 and 26, respectively, and for walls P2 IA and P6 IA in Figs. 27 and 28, respectively. On Wall P6, the cracks prior to the test, which arose at the time of the injection of the wall, are shown in zigzag lines and grey color.

The first cracks arose at about $50 \%-60 \%$ of the maximum load. Similarly to the unreinforced walls, these cracks are visible only in the mortar joint, with a predominantly horizontal direction, which indicates the crushing of the mortar. For a load level close to $90 \%$ of the maximum load, the cracking intensified and the breakage of the stone elements was already visible. Also, in this case, there was vertical cracking with detachment of the grout joint
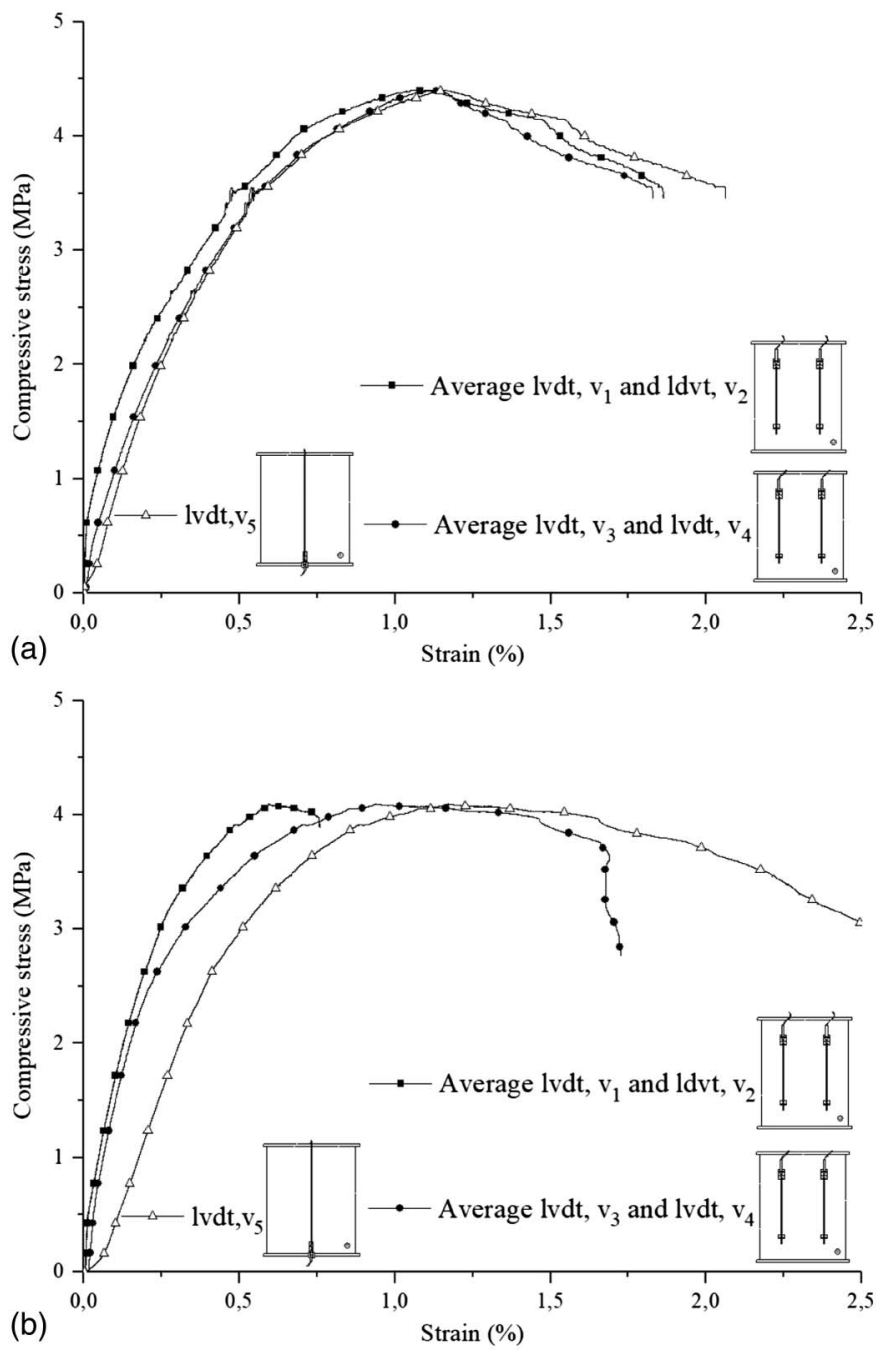

Fig. 17. Compressive stress-vertical extension graphs: (a) P1 IB; and (b) P3 IB.

and out-of-plane movements (Fig. 29). In the case of Wall P6 1A, a localized rotation on Face A was found near the top of the plane after reaching the maximum load. This latter effect resulted in the measurement of a displacement lower than the one actually experienced. This phenomenon was responsible for the fact that, near 

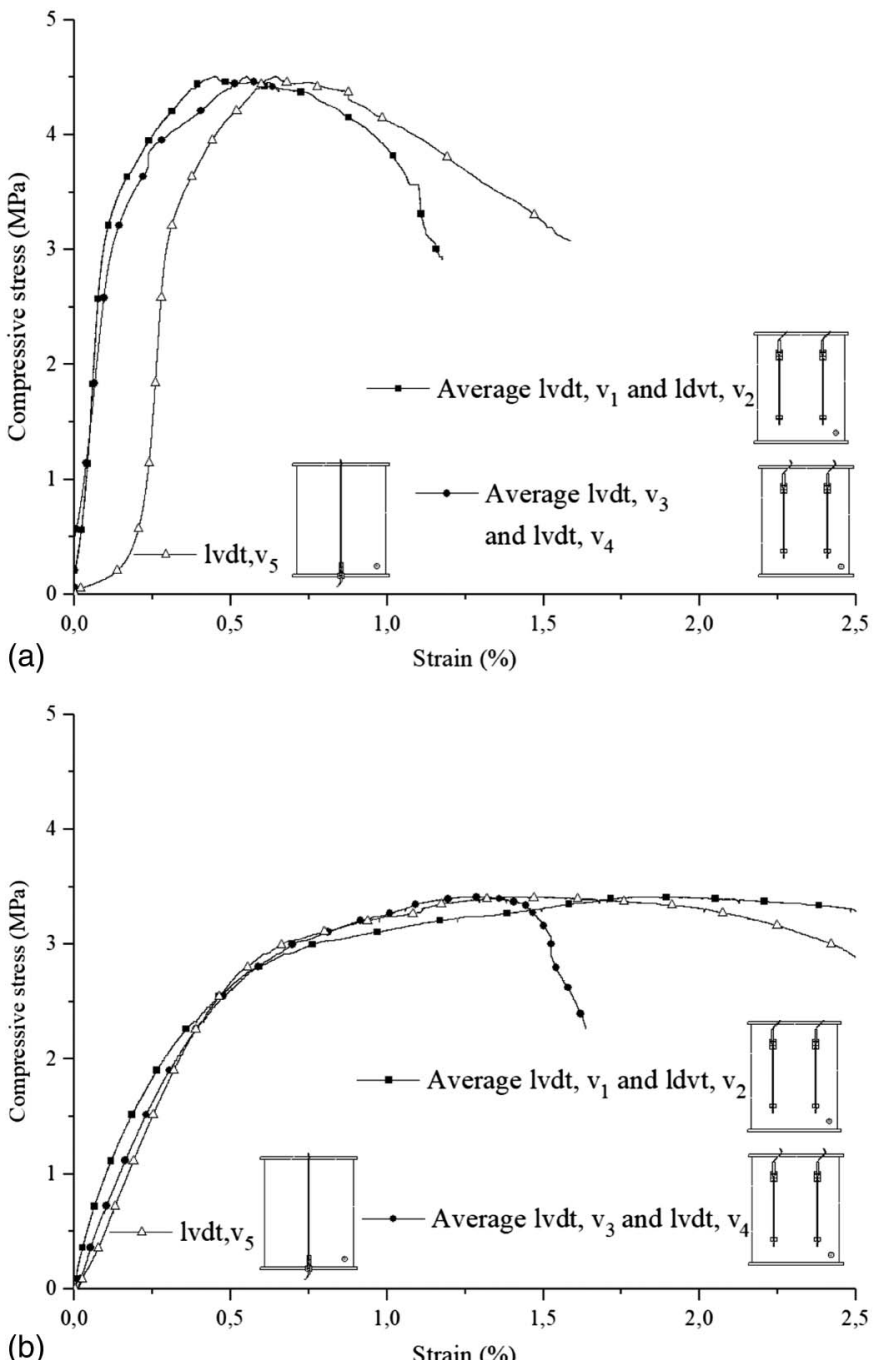

Fig. 18. Compressive stress-vertical extension graphs: (a) P2 IA; and (b) P6 IA. the end of the test, there was a change of direction of the displacements measured in LVDTs v1 and v2. From the analysis of the cracking distribution, it can be seen that, similarly to the unreinforced walls, there was a predominance of cracks in the upper zone, as shown in Figs. 30 and 31. The appearance of the interior of the injected walls during the dismantling can be seen in Figs. 32 and 33. Comparing these results to those of Fig. 16, where the existence of voids in the noninjected specimens is clear, in these pictures, it is possible to check that injected grout was very well distributed for both grout types, filling the voids of the wall.

\section{Comparison of Results}

Following the analysis of the results of each wall, Fig. 34 shows the vertical stress-strain diagrams for the six walls tested, with and without grouting, in order to facilitate comparison. In Table 6, the average values obtained in each type of strengthened wall are compared with the mean values obtained on the unstrengthened walls. It is found that the injection significantly increased the compressive strength of the walls (about three times) and also the stiffness of the walls, about five times. The two grouts seem to have performed similarly in terms of strength and initial stiffness.

The appearance of the first horizontal and vertical cracks, as well as the respective applied load, is given in Figs. 35 and 36, respectively. On average, the first horizontal cracks appeared at about $50 \%$ of the maximum load, whereas vertical cracks arose at about $80 \%$ of the maximum load. Crack initiation was defined by the LVDTs and is rather objective, corresponding to a significant increase of measurements.

Several compression tests on masonry walls in order to evaluate the injection technique effectiveness were conducted over the last few years. It is therefore inevitable to compare these results with the results of the experimental campaign presented here (Valluzi 2000; Valluzi et al. 2001; Valluzzi et al. 2004; Vintzileou 2007; Silva 2008; Silva et al. 2014; Almeida et al. 2012; Toumbakari 2002; Miltiadou-Fezans et al. 2006). A summary of these results is show in Table 7.
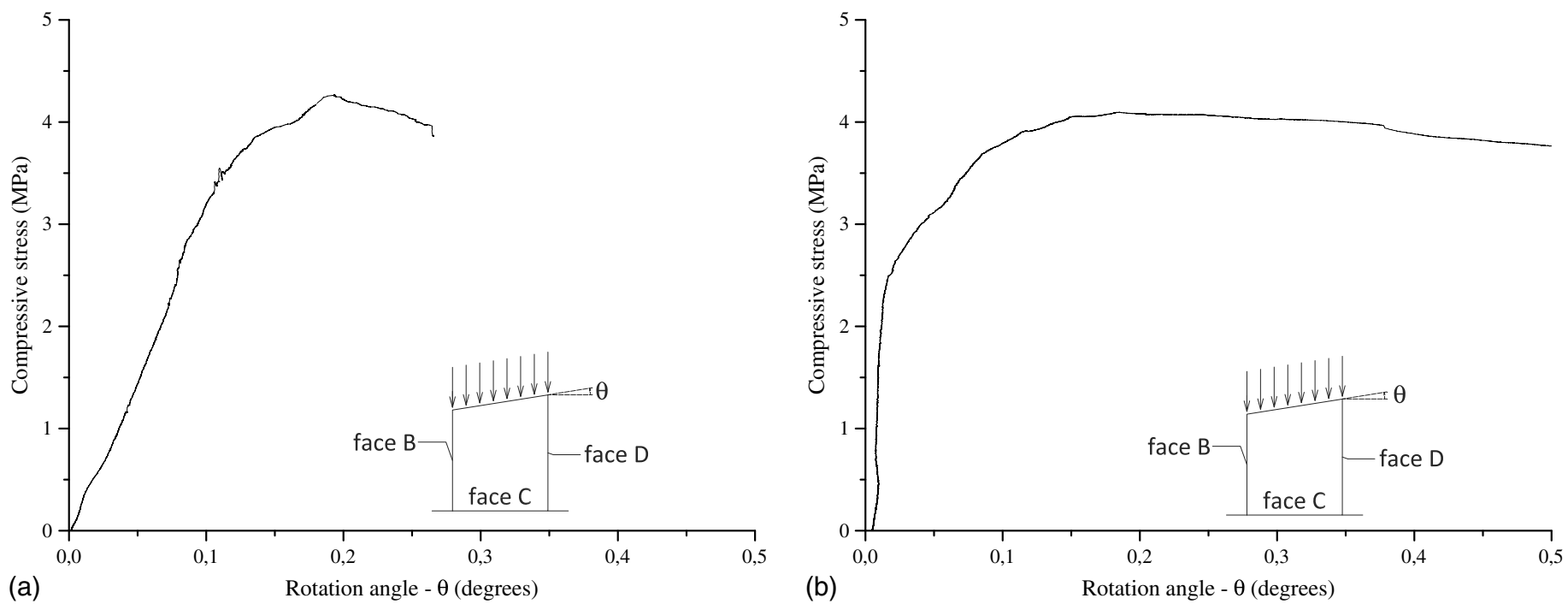

Fig. 19. Compressive stress-rotation angle of the walls: (a) P1 IB; and (b) P3 IB. 


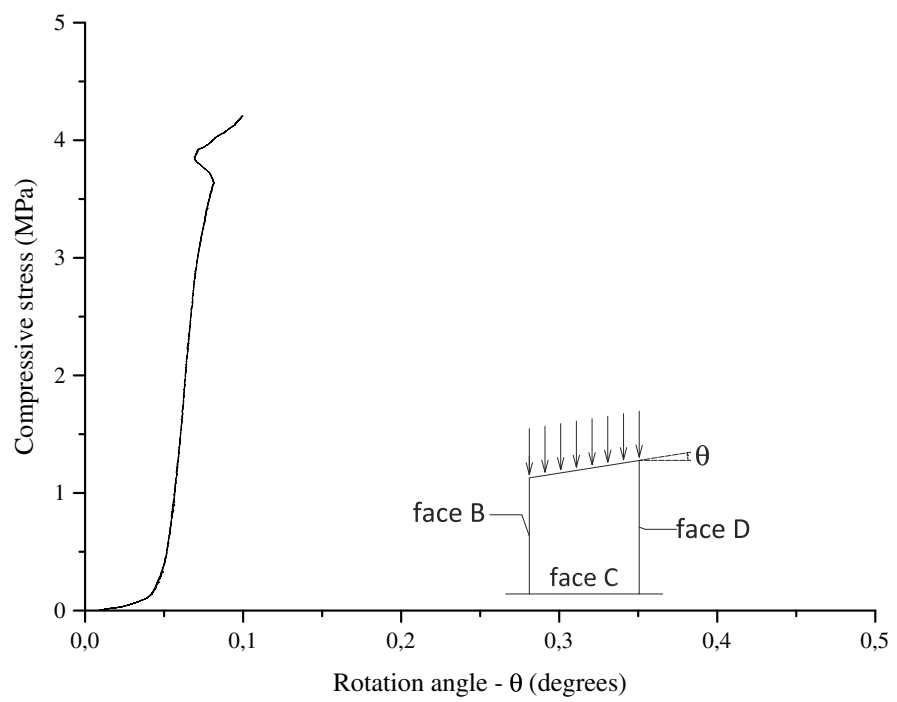

(a)

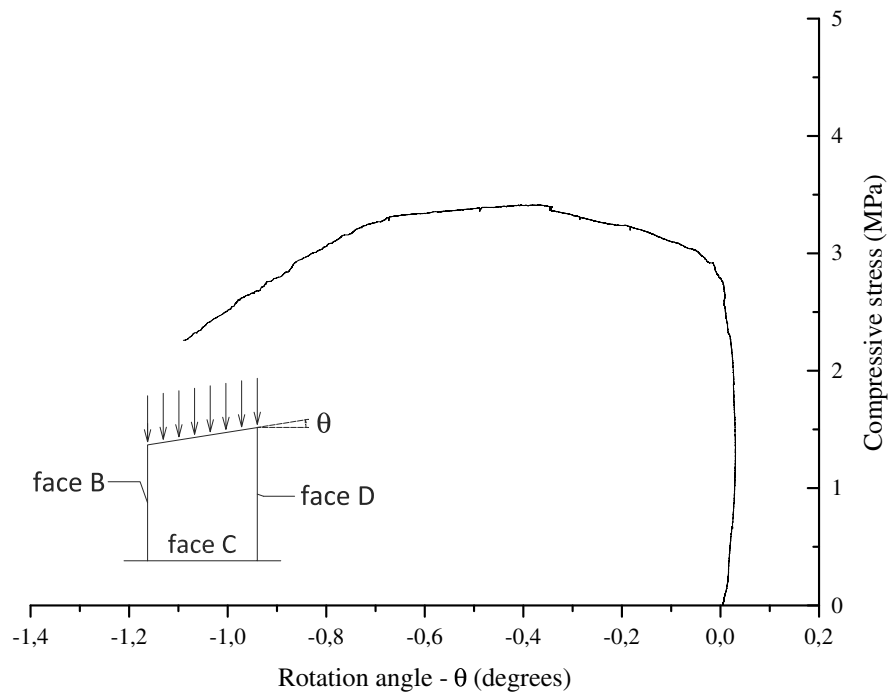

(b)

Fig. 20. Ratio of compressive stress versus angle of rotation of the walls: (a) P2 IA; and (b) P6 IA.
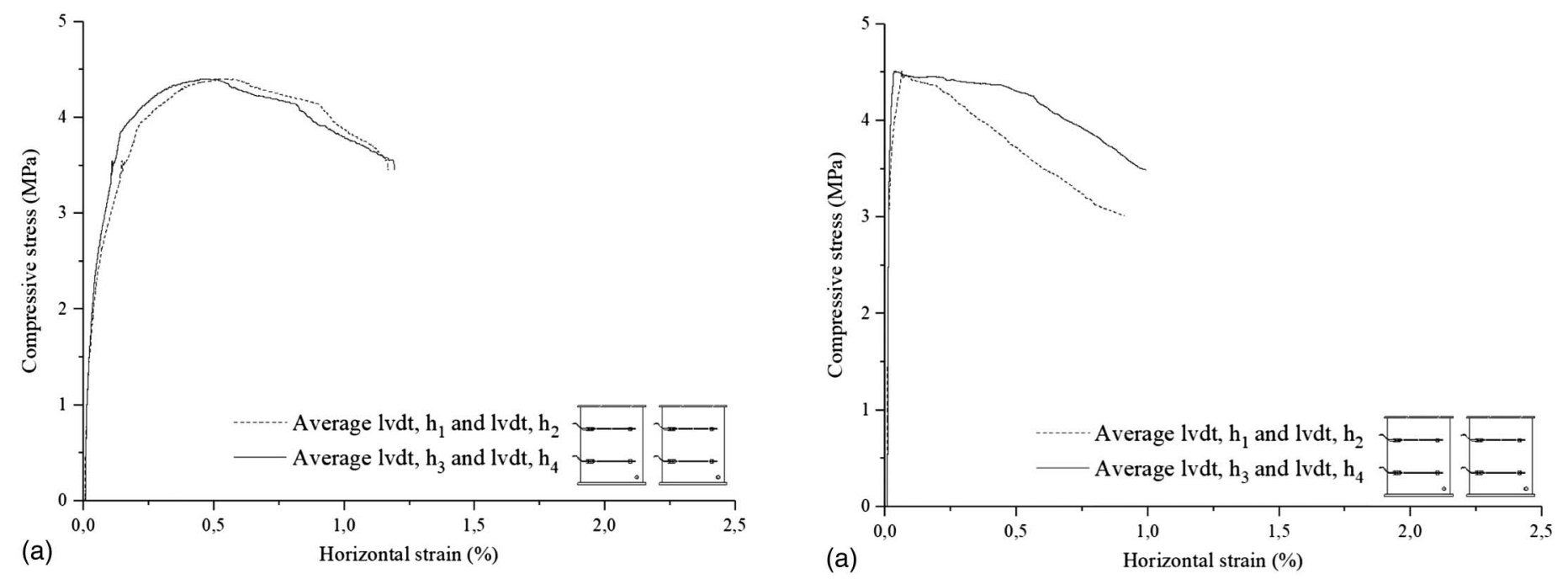

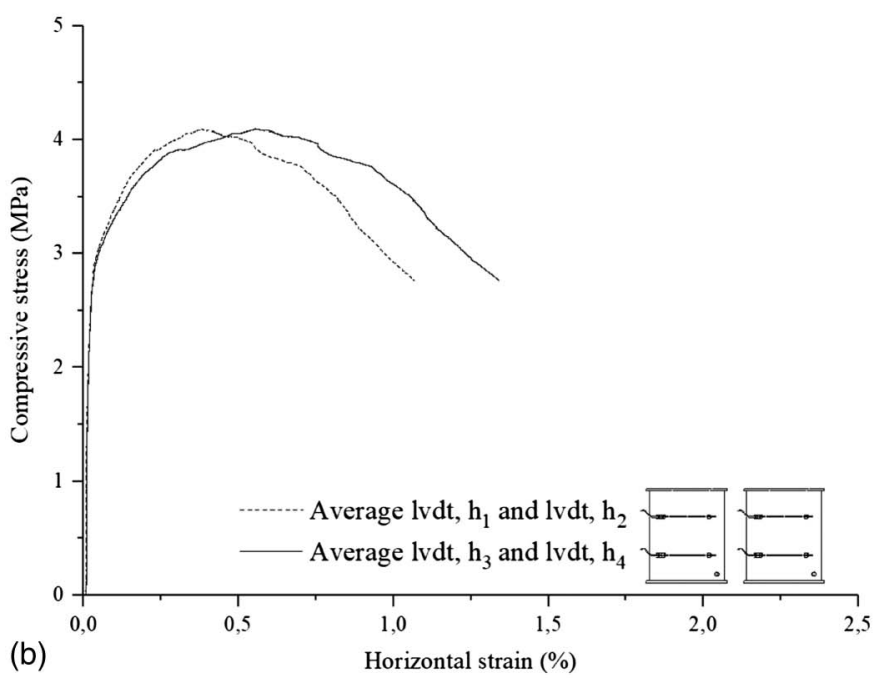

Fig. 21. Compressive stress-horizontal extension graphs: (a) P1 IB; and (b) P3 IB.

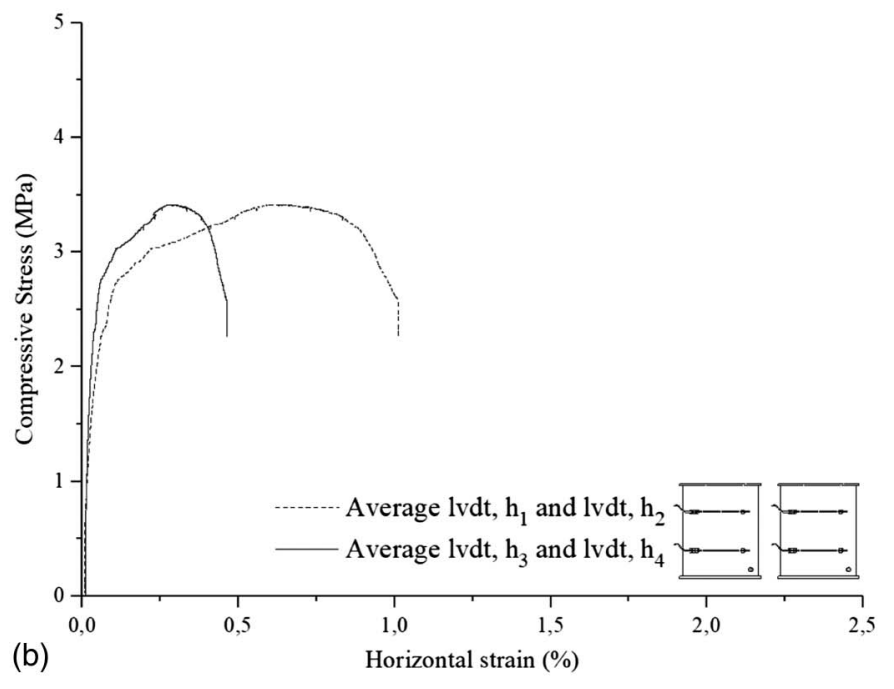

Fig. 22. Compressive stress-horizontal extension graphs: (a) P2 IA; and (b) P6 IA. 

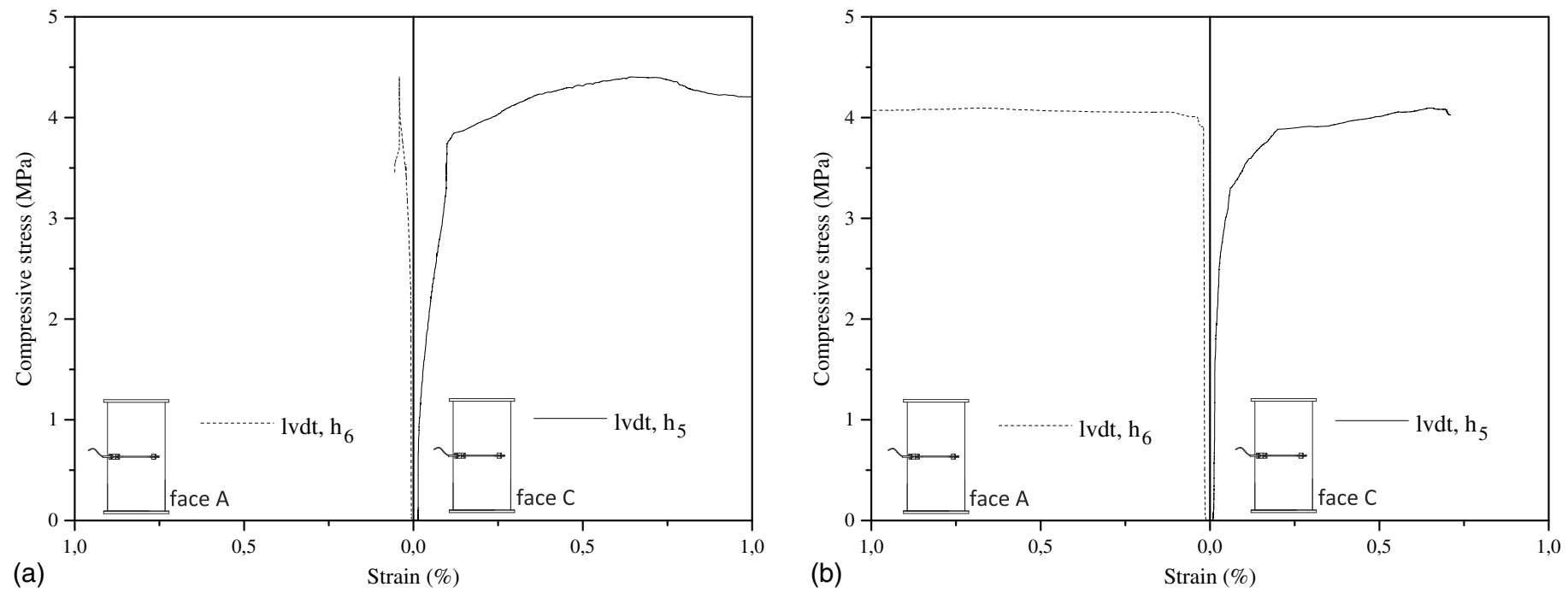

Fig. 23. Graphs of compressive stress-horizontal extension on transverse Faces A and C: (a) P1 IB; and (b) P3 IB.
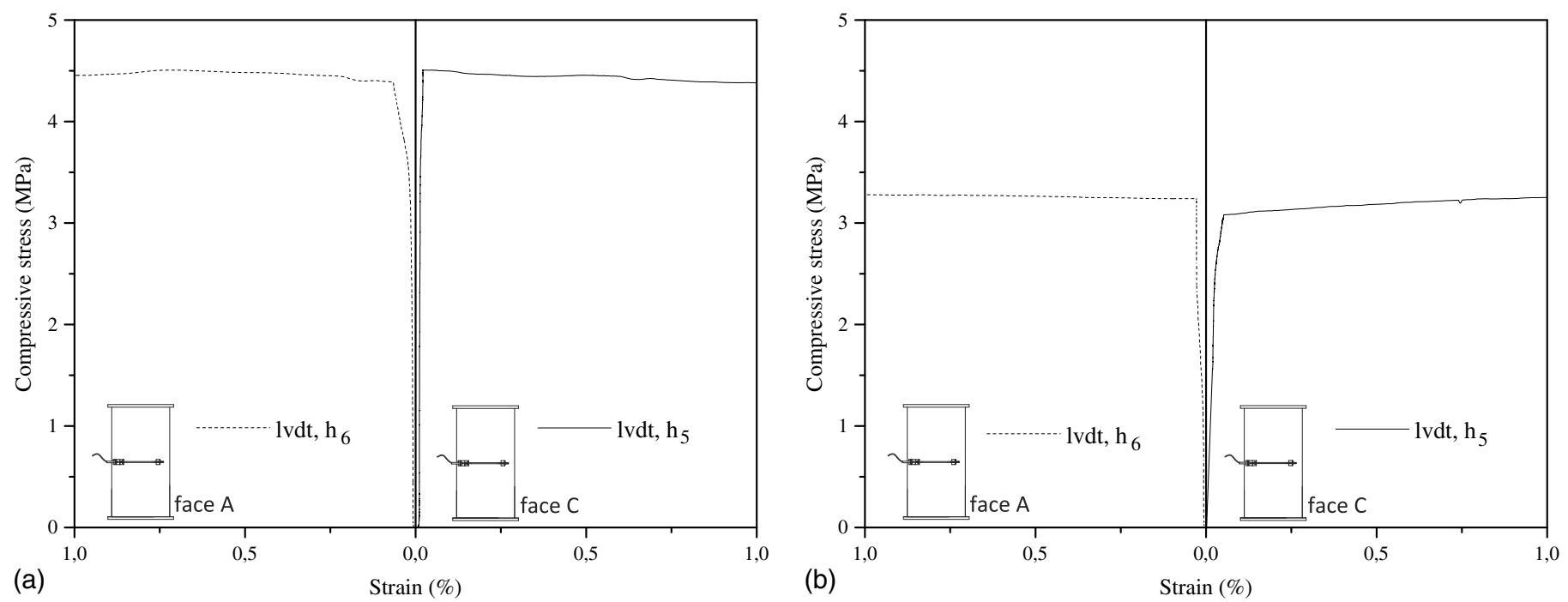

Fig. 24. Graphs of compressive stress-horizontal strain on transverse Faces A and C: (a) P2 IA; and (b) P6 IA.

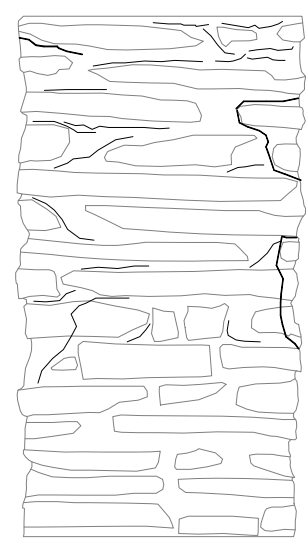

Face A

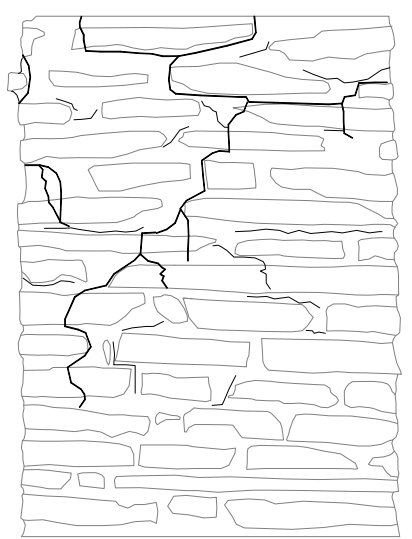

Face B

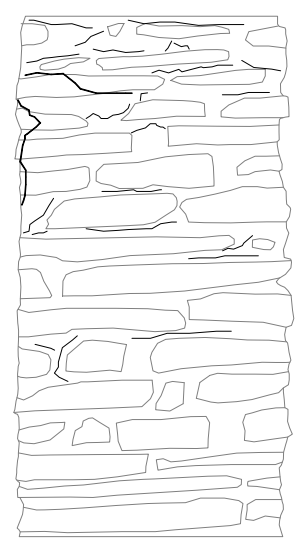

Face C

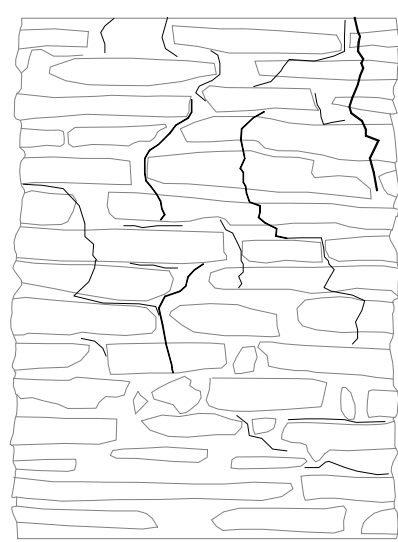

Face D

Fig. 25. Crack pattern corresponding to the end of the test in P1 IB. 


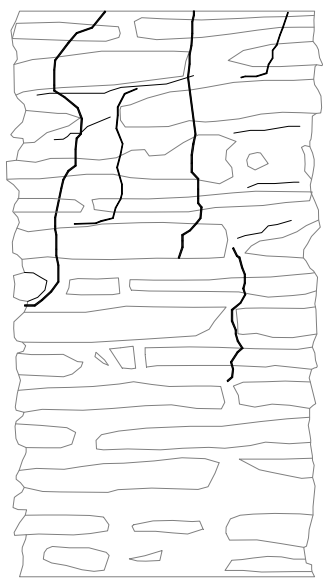

Face A

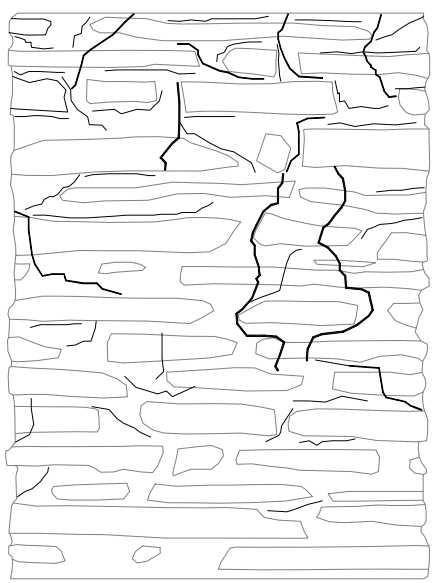

Face B

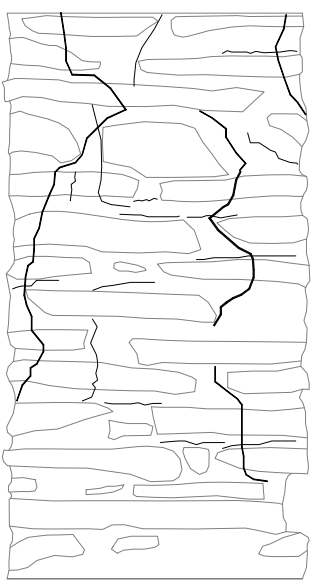

Face C

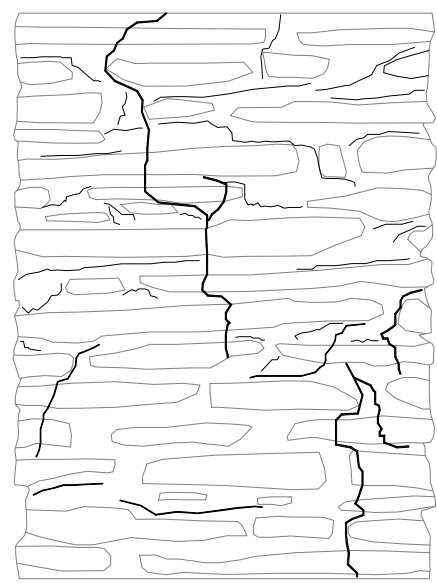

Face D

Fig. 26. Crack pattern corresponding to the end of the test in P3 IB.

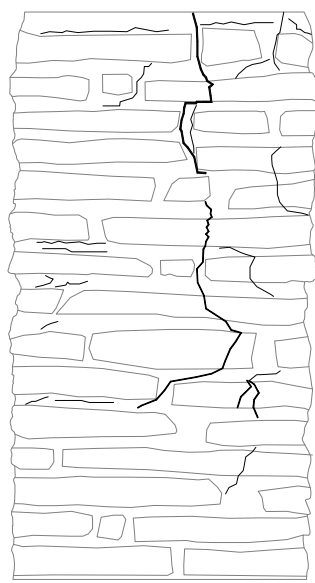

Face A

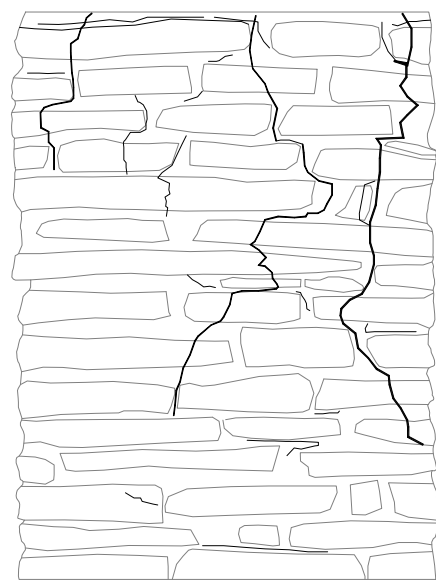

Face B

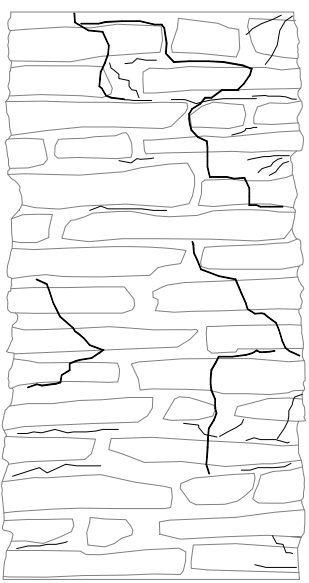

Face C

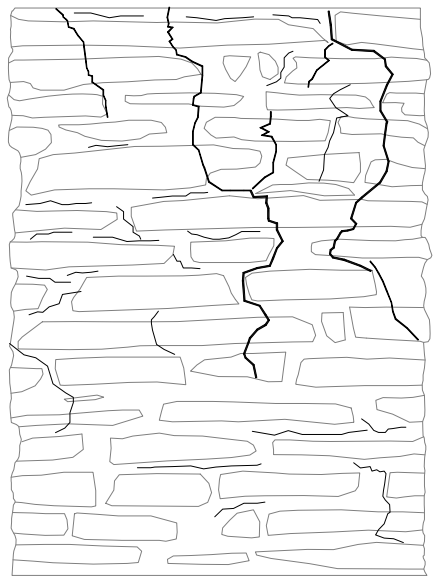

Face D

Fig. 27. Crack pattern corresponding to the end of the test in P2 IA.

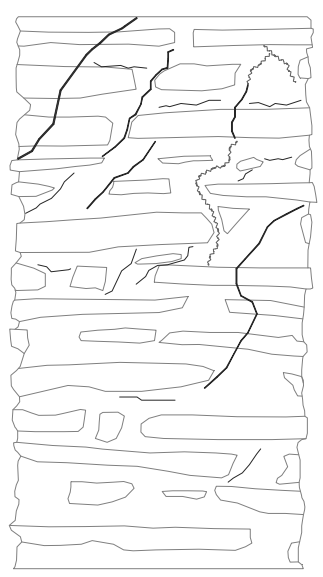

Face A

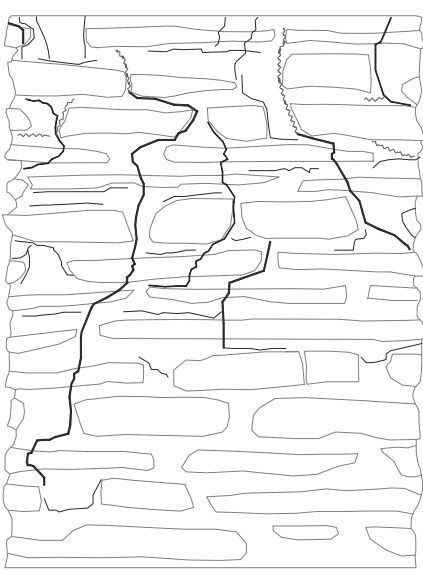

Face B

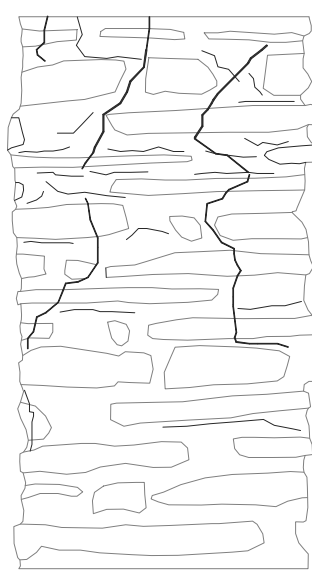

Face C

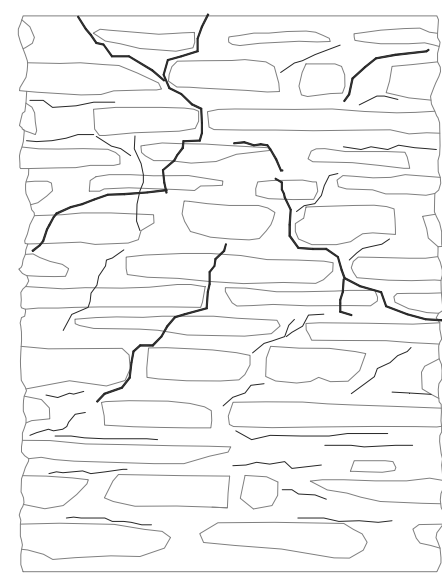

Face D

Fig. 28. Crack pattern corresponding to the end of the test in P6 IA. 


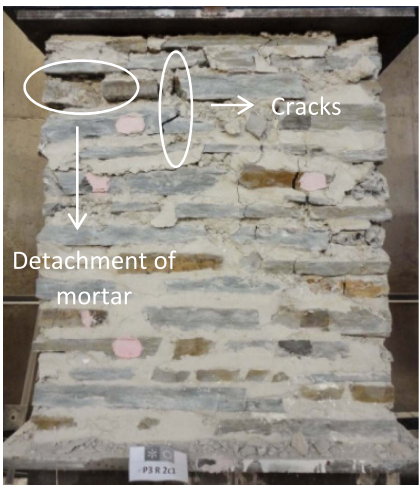

(a)

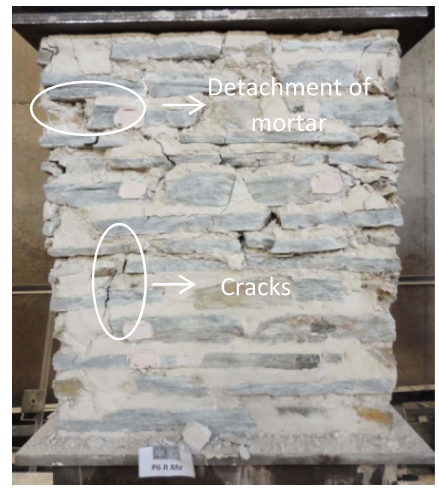

(b)
Fig. 29. Collapse mechanism of the walls: (a) P3 IB; and (b) P6 IA.
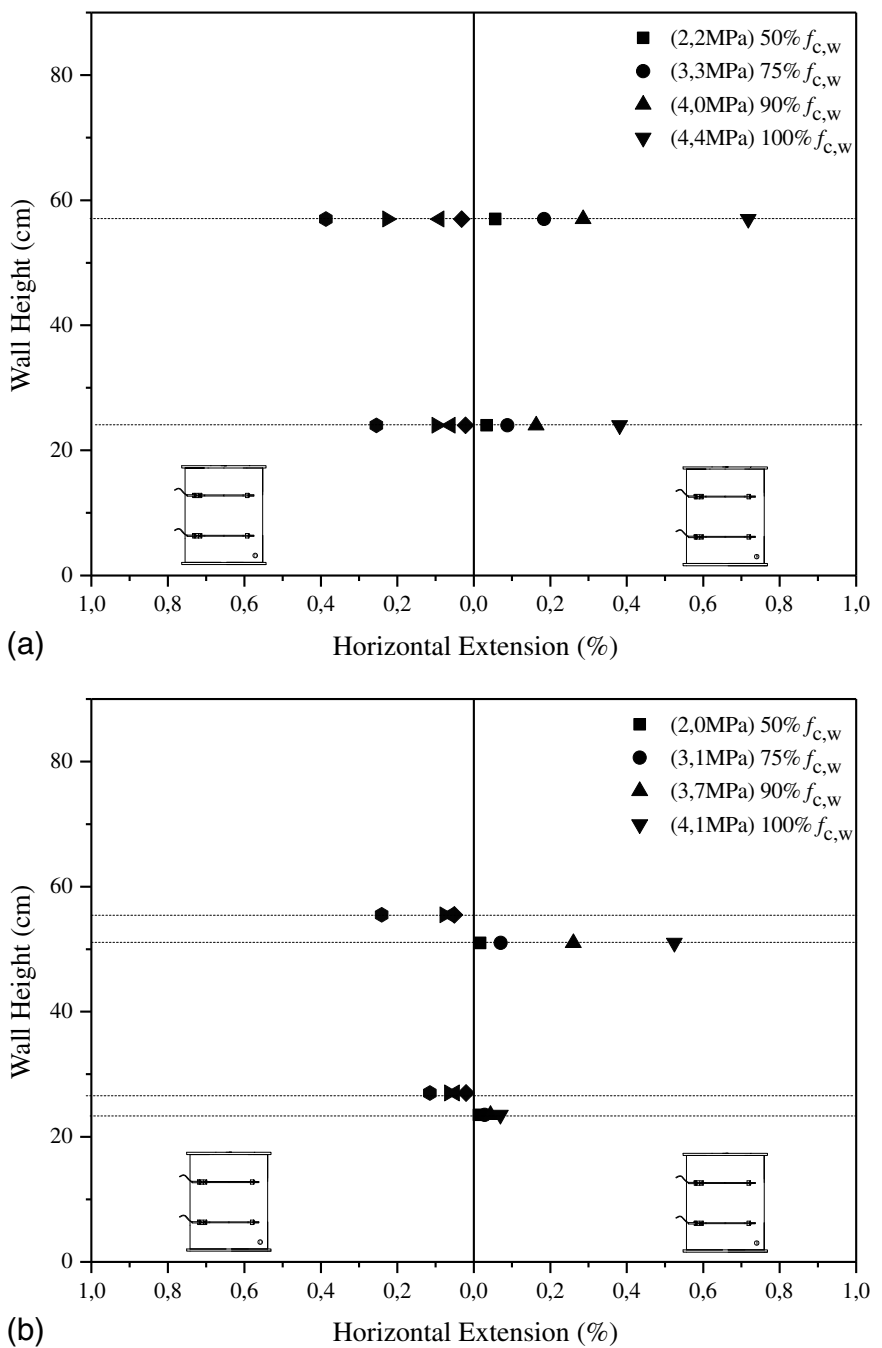

(b)

Horizontal Extension (\%)

Fig. 30. Variation of the horizontal extension with the variation of load and height of the wall: (a) P1 IB; and (b) P3 IB.

A common result is that injection increases the load capacity and stiffness of the walls. Direct comparison of the remaining values is risky because the procedures and test schemes are different from work to work, with multiple aspects that influence the results
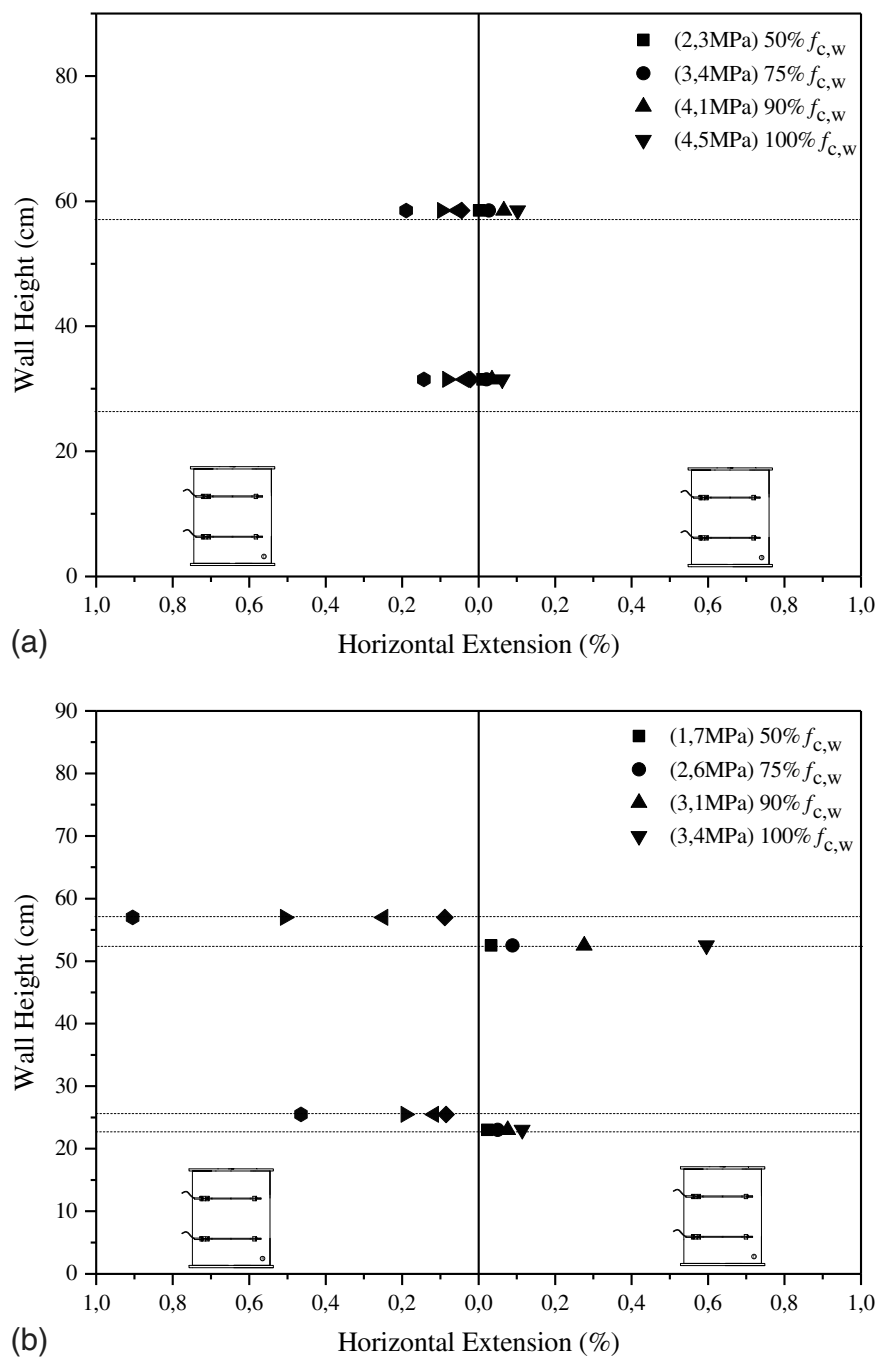

Fig. 31. Variation of the horizontal extension with the variation of load and height of the wall: (a) P2 IA; and (b) P6 IA.

obtained. In addition, the walls tested in this work present a different constructive typology of the walls of three leaves often used in previous works. Also, the analytical models presented in the literature to estimate compressive strength were formulated for threeleaf masonry walls (Egermann and Newald-Burg 1994; Vintzileou and Tassios 1995; Pina-Henriques 2005; Vintzileou and MiltiadouFezans 2008) considering the geometrical characteristics of the walls, namely the width of the leaves and compressive strength of the exterior and interior leaves. These models are not for the type of masonry presented in this paper. Italian regulations (OPCM 2005) recommend increasing the mechanical characteristics through injection to the double, which the present work confirms as conservative, meaning that it can be adequate for practical purposes.

\section{Conclusions}

This paper addresses the use of grout in single-leaf walls made of shale stone from the north of Portugal and a lime-based mortar. The typological and geometrical characteristics of the walls were tested, which is also described, as well as the mechanical properties of the mortar. Two of the built walls were not strengthened, and the 


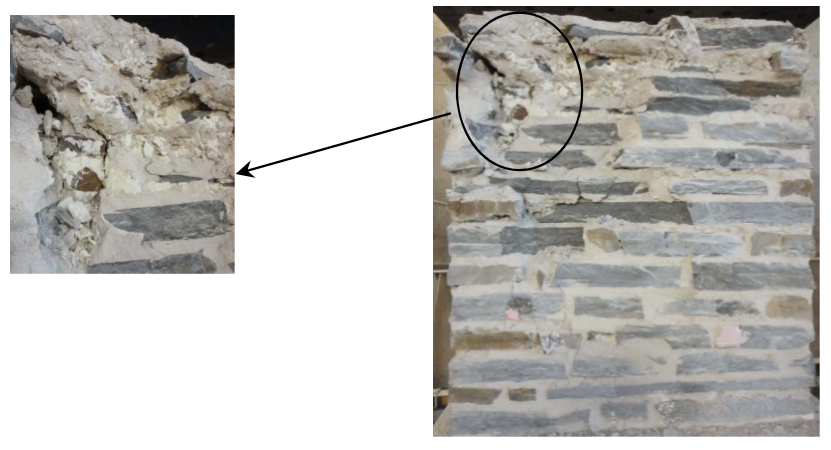

(a) (b)

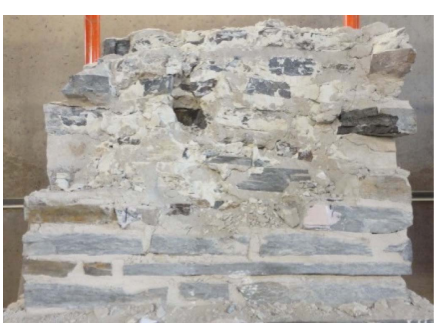

(c)

Fig. 32. Appearance of the interior of Wall P1 IB: (a) detail of the top; (b) top of the wall; and (c) wall base.

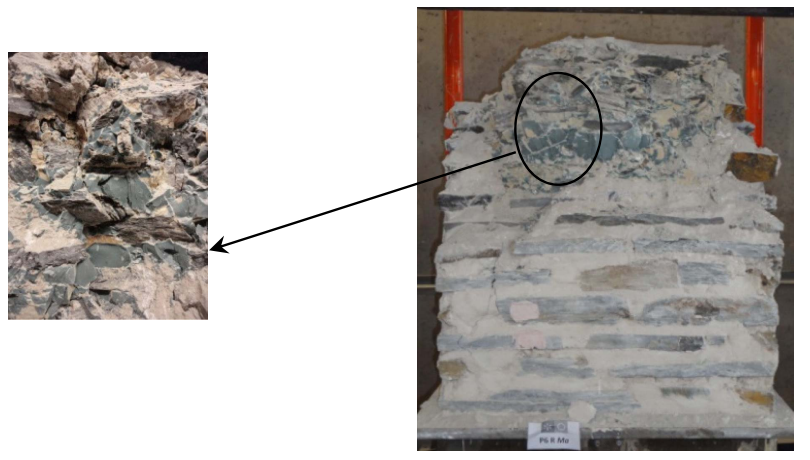

(a)

(b)

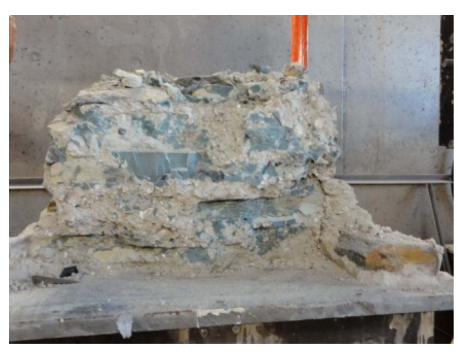

(c)

Fig. 33. Appearance of the interior of Wall P6 IA: (a) detail of the top; (b) top of the wall; and (c) wall base.

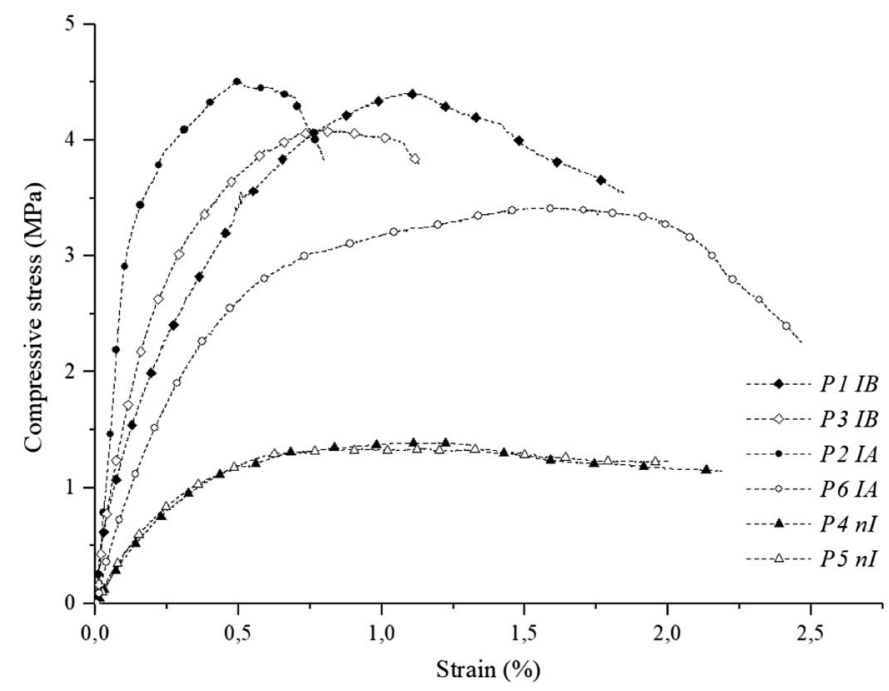

Fig. 34. Compressive stress-strain graphs for all tested walls.

Table 6. Comparison of the mean values obtained in the tests in each type of reinforced wall with the average obtained in the two nonreinforced walls

\begin{tabular}{lccccc}
\hline Walls & $\begin{array}{c}\Delta f_{c} \\
(\%)\end{array}$ & $\begin{array}{c}\Delta \varepsilon_{v, p} \\
(\%)\end{array}$ & $\begin{array}{c}\Delta \varepsilon_{h, p} \\
(\%)\end{array}$ & $\begin{array}{c}\Delta E_{0} \\
(\%)\end{array}$ & $\begin{array}{c}\Delta E_{30-60} \\
(\%)\end{array}$ \\
\hline (P2 + P6) IA & +188 & $+4,5$ & -42 & +410 & +441 \\
$(\mathrm{P} 1+\mathrm{P} 3) \mathrm{IB}$ & +210 & -10 & +2 & +373 & +145 \\
\hline
\end{tabular}

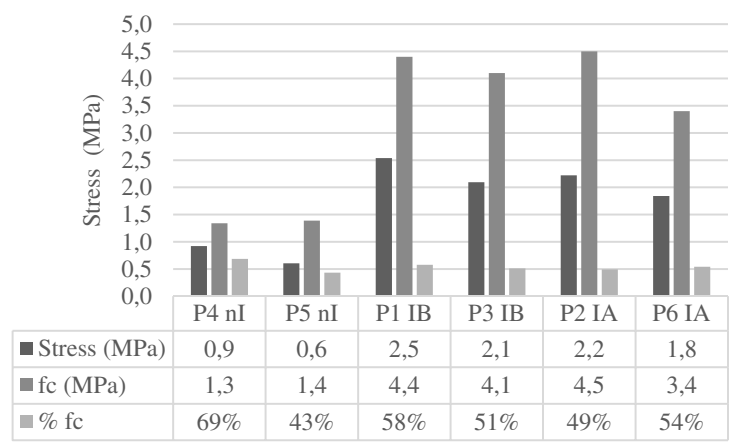

Fig. 35. Compressive stress level for which the first crack with horizontal direction appears versus maximum compressive strength.

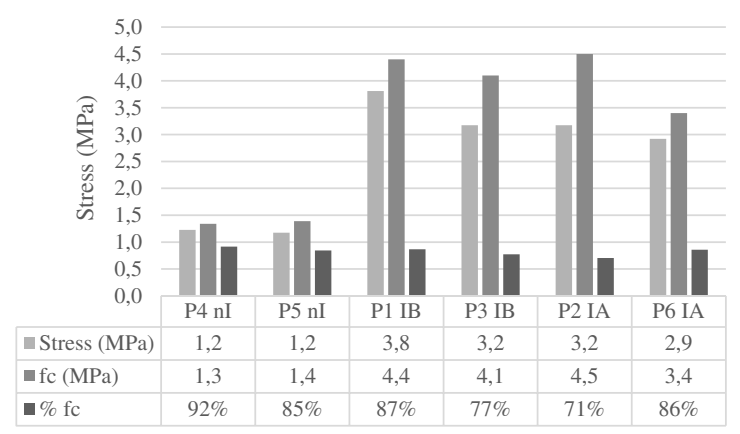

Fig. 36. Compressive stress level for which the first crack with vertical direction appears versus maximum compressive strength. 
Table 7. Data obtained from experimental tests of stone wall models

\begin{tabular}{|c|c|c|c|c|c|c|}
\hline \multirow[b]{2}{*}{ Authors } & \multicolumn{2}{|c|}{ Injection grouts } & \multirow{2}{*}{$\begin{array}{c}\text { Wall } \\
\text { dimensions } \\
(\mathrm{cm})\end{array}$} & \multicolumn{3}{|c|}{ Variation after injection $(\%)$} \\
\hline & $\begin{array}{c}\text { Composition or } \\
\text { author designation }\end{array}$ & $\begin{array}{l}\text { Compressive strength } \\
\text { at } 28 \text { days (MPa) }\end{array}$ & & $f_{c}$ & $E$ & $f_{t}$ \\
\hline Vintzileou and Tassios (1995) & $\begin{array}{l}\mathrm{A} \\
\mathrm{B}\end{array}$ & $\begin{array}{l}30 \\
13\end{array}$ & $40 \times 60 \times 120$ & $\begin{array}{l}150 \\
200\end{array}$ & $\begin{array}{l}37^{\mathrm{a}} \\
50^{\mathrm{a}}\end{array}$ & $64^{\mathrm{b}}$ \\
\hline Miltiadou-Fezans et al. (2006) & $\begin{array}{l}\text { NHL5 } \\
\text { Ternary } \\
\text { NHL5 }\end{array}$ & $\begin{array}{l}2.82 \\
4.08 \\
2.82\end{array}$ & $45 \times 104 \times 120$ & $\begin{array}{r}65 \\
116 \\
65\end{array}$ & $\begin{array}{c}20^{\mathrm{c}} \\
0.08^{\mathrm{c}} \\
-13^{\mathrm{c}}\end{array}$ & $\begin{array}{l}110 \\
230 \\
120\end{array}$ \\
\hline Toumbakari (2002) & $\begin{array}{c}13 b-10 \\
\text { Cb-0 } \\
13 b-0\end{array}$ & $\begin{array}{r}6.4 \\
14.6 \\
5.2\end{array}$ & $40 \times 60 \times 120$ & $\begin{array}{l}61 \\
62 \\
21\end{array}$ & $\begin{array}{r}125^{\mathrm{d}} \\
37^{\mathrm{d}} \\
-30^{\mathrm{d}}\end{array}$ & $\begin{array}{c}0.06 \\
97 \\
107\end{array}$ \\
\hline Valluzi (2000) and Valluzi et al. (2001) & $\begin{array}{c}\text { FenX-A+F } \\
\text { FenX-B }\end{array}$ & $\begin{array}{l}5.10 \\
3.23\end{array}$ & $50 \times 80 \times 140$ & $\begin{array}{l}46 \\
13\end{array}$ & $\begin{array}{l}21^{\mathrm{e}} \\
93^{\mathrm{e}}\end{array}$ & - \\
\hline Silva (2008) & Commercial grout & $12^{\mathrm{f}}$ & $30 \times 60 \times 110$ & $80^{\mathrm{g}}$ & $1^{\mathrm{e}}$ & - \\
\hline Almeida et al. (2012) & $\mathrm{CL}+\mathrm{HL}+\mathrm{S}$ & 0.50 & $40 \times 120 \times 250^{\mathrm{h}}$ & 60 & $40^{\mathrm{i}}$ & - \\
\hline
\end{tabular}

${ }^{a}$ Corresponding to the tangent of $1 / 3$ of the average compressive strength.

${ }^{\mathrm{b}}$ Considered by the authors $f_{w t, 0}=0,1 \mathrm{MPa}$.

${ }^{\mathrm{c}}$ Without reference about the procedure.

${ }^{\mathrm{d}}$ Corresponding to $30 \%$ of the respective compressive strength.

${ }^{\mathrm{e}}$ Corresponding to $30 \%-60 \%$ of the respective compressive strength.

${ }^{\mathrm{f}}$ Manufacturer data.

${ }^{\mathrm{g}}$ A prior state of damage was not applied. The displayed value is relative to a reference wall.

${ }^{\mathrm{h}}$ Tests on real walls, so the dimensions are approximate.

${ }^{\mathrm{i}}$ After loading-unloading cycles.

remaining four walls were strengthened with two different grouts. One grout was commercially available from the Mapei Company, and the other was prescribed in the laboratory. The injection process was very similar, with good injectability for both grouts. The consumption of the prescribed grout in the injection of the two walls was similar. In the case of the commercial grout, the quantity injected in the two walls was different due to the typology of the specimen, which led to some dispersion of the results.

Finally, the results of the uniaxial compression tests carried out on the walls, not strengthened and strengthened with injection, were discussed in this paper. These tests took place 90 days after the injection and allowed evaluation of the influence of this strengthening technique on the behavior of this typology of walls under vertical actions. It was found that: (a) the injection technique led to an increase in compressive strength of three times and an increase to the modulus of elasticity of five times, and (b) the applied strengthening technique did not lead to a significant difference in strains corresponding to the maximum stress, thus increasing the brittleness of the response.

\section{References}

Almeida, C., J. P. Guedes, A. Arêde, C. Q. Costa, and A. Costa. 2012. "Physical characterization and compression tests of one leaf stone masonry walls." Constr. Build. Mater. 30: 188-197. https://doi.org/10 .1016/j.conbuildmat.2011.11.043.

ASTM. 2002. Standard test method for static modulus of elasticity and Poisson's ratio of concrete in compression. ASTM C469. West Conshohocken, PA: ASTM.

ASTM. 2010a. Standard test method for expansion and bleeding of freshly mixed grouts for preplaced-aggregate concrete in the laboratory. ASTM C940. West Conshohocken, PA: ASTM.

ASTM. 2010b. Standard test method for flow of grout for preplacedaggregate concrete (flow cone method). ASTM C939. West Conshohocken, PA: ASTM.
Barros, R. 2013. "Avaliação do comportamento material e estrutural de construções em xisto." [In Portuguese.] Ph.D. thesis, Dept. of Civil Engineering, Univ. of Minho.

Barros, R. S., D. V. Oliveira, and H. Varum. 2010. "Typological characterization of the Portuguese traditional schist constructions." In Proc., 37th IAHS World Congress on Housing Science: Design, Technology, Refurbishment and Management of Buildings. Coral Gables, FL: International Association for Housing Science.

Barros, R. S., D. V. Oliveira, H. Varum, C. A. Alves, and A. Camões. 2014. "Experimental characterization of physical and mechanical properties of schist from Portugal" Constr. Build. Mater. 50: 617-630. https://doi .org/10.1016/j.conbuildmat.2013.10.008.

Biçer-Simsir, B., and L. Rainer. 2011. "Evaluation of lime-based hydraulic injection grouts for the conservation of architectural surfaces." In Proc., A Manual of Laboratory and Field Test Methods. Los Angeles: GCI.

Billong, N., U. C. Melo, D. Njopwouo, F. Louvet, and J. P. Bonnet. 2009. "Effect of mixture constituents on properties of slaked limemetakaolin-sand mortars containing sodium hydroxide" Cem. Concr. Compos. 31 (9): 658-662. https://doi.org/10.1016/j.cemconcomp.2009 .06 .001 .

Binda, L., G., Baronio, and T. Squarcina. 1992. "Evaluation of the durability of bricks and stones and of preservation treatments." In Proc., 7th Int. Congress on Deterioration and Conservation of Stone: Held in Lisbon. Lisbon, Portugal: LNEC.

Brooks, J. J., and M. M. Johari. 2001. "Effect of metakaolin on creep and shrinkage of concrete" Cem. Concr. Compos. 23 (6): 495-502. https:// doi.org/10.1016/S0958-9465(00)00095-0.

Cachim, P., A. L. Velosa, and F. Rocha. 2010. "Effect of Portuguese metakaolin on hydraulic lime concrete using different curing conditions" Constr. Build. Mater. 24 (1): 71-78. https://doi.org/10.1016/j .conbuildmat.2009.08.010.

CEN (European Committee for Standardization). (1999). Methods of test for mortar for masonry. Part 11: Determination of flexural and compressive strength of hardened mortar. EN 1015-11. Brussels, Belgium: CEN.

CEN (European Committee for Standardization). (2001). Tests for mechanical and physical properties of aggregates. Determination of 
water content by drying in a ventilated oven. EN 1097-5. Brussels, Belgium: CEN.

CEN (European Committee for Standardization). (2005). Eurocode 6. Design of masonry structures; Part 1-1: General rules for reinforced and unreinforced masonry structures. EN 1996-1-1. Brussels, Belgium: CEN.

CEN (European Committee for Standardization). (2016): Methods of testing cement. Part 1: Determination of strength. EN 196-1. Brussels, Belgium: CEN.

Egermann, R., and C. Newald-Burg. 1994. "Assessment of the load bearing capacity of historic multiple leaf masonry walls." In Proc., 10th Int. Brick Block Masonry Conf., 1603-1612. Mississauga, ON, Canada: Masonry Council of Canada.

Gleize, P. J., M. Cyr, and G. Escadeillas. 2007. "Effects of metakaolin on autogenous shrinkage of cement pastes" Cem. Concr. Compos. 29 (2): 80-87. https://doi.org/10.1016/j.cemconcomp.2006.09.005.

Kalagri, A., A. Miltiadou-Fezans, and E. Vintzileou. 2010. "Design and evaluation of hydraulic lime grouts for the strengthening of stone masonry historic structures" Mater. Struct. 43 (8): 1135-1146. https://doi .org/10.1617/s11527-009-9572-1.

Lee, S. T., H. Y. Moon, R. D. Hooton, and J. P. Kim. 2005. "Effect of solution concentrations and replacement levels of metakaolin on the resistance of mortars exposed to magnesium sulphate solutions" Cem. Concr. Res. 35 (7): 1314-1323. https://doi.org/10.1016/j .cemconres.2004.10.035.

Luso, E. 2012. "Experimental analysis of lime based grouts for the ancient masonry injections.” Ph.D. thesis, Dept. of Civil Engineering, Univ. of Minho.

Luso, E., and P. B. Lourenço. 2016. "Experimental characterization of commercial lime based grouts for stone masonry consolidation" Constr. Build. Mater. 102 (Part 1): 216-225. https://doi.org/10.1016/j .conbuildmat.2015.10.096.

Luso, E., and P. B. Lourenço. 2017a. "Bond strength characterization of commercially available grouts for masonry." Constr. Build. Mater. 144: 317-326. https://doi.org/10.1016/j.conbuildmat.2017.03.179.

Luso, E., and P. B. Lourenço. 2017b. "Experimental laboratory design of lime based grouts for masonry consolidation." Int. J. Architect. Heritage 11 (8): 1143-1152. https://doi.org/10.1080/15583058.2017.1354095.

Melo, K. A., and A. M. Carneiro. 2010. "Effect of metakaolin's finesses and content in self-consolidating concrete" Constr. Build. Mater. 24 (8): 1529-1535. https://doi.org/10.1016/j.conbuildmat.2010.02.002.

Miltiadou-Fezans, A., E. Papakonstantinou, K. Zambas, A. Panou, and K. Frantzikinaki. 2005. "Design and application of hydraulic grouts of high injectability for the structural restoration of the column drums of the Parthenon Opisthodomos." Trans. Built Environ. 83: 461-471.

Miltiadou-Fezans, A., E. Vintzileou, E. Papadopoulou, and A. Kalagri. 2006. "Mechanical properties of three-leaf stone masonry after grouting." In Proc., Structural Analysis of Historical Constructions, edited by P. B. Lourenço, P. Roca, C. Modena, and S. Agrawal. Panaji, India: Fundação Oriente.

Oliveira, D. V., R. A. Silva, E. Garbin, and P. B. Lourenço. 2012. "Strengthening of three-leaf stone masonry walls: an experimental research" Mater. Struct. 45 (8): 1259-1276. https://doi.org/10.1617/s11527 -012-9832-3.

OPCM (Ordinanza del Presidente del Consiglio dei Ministri). 2005. Primi elementi in materia di criteri generali per la classificazione sismica del territorio nazionale e di normative tecnicheper le costruzioni in zona sismica: Ordinanza P.C.M. n. 3431. [In Italian.] Official Bulletin n. 107. Rome: OPCM.
Papayianni, I., and V. Pachta. 2015. "Experimental study on the performance of lime-based grouts used in consolidating historic masonries" Mater. Struct. 48 (7): 2111-2121. https://doi.org/10.1617/s11527-014 -0296-5.

Perret, S. 2002. "Rôle du degré de saturation dês sables fins à moyens sur leur injectabilité par dês coulis de ciment microfin." Thèse de Doctorat ès Sciences appliquées, Spécialité: Génie Civil, Université de Sherbrooke.

Pina-Henriques, J. 2005. "Masonry under compression: Failure analysis and long-term effects." Ph.D. dissertation, Departamento de Engenharia Civil da, Universidade do Minho.

Rodrigues, M. P. 2004. "Argamassas de Revestimento para Alvenarias Antigas. Contribuição para o estudo da influência dos ligantes." Ph.D. Tese, Dept. of Civil Engineering, University of NebraskaLincoln.

Sepulcre-Aguilar, A., and F. Hernández-Olivares. 2010. "Assessment of phase formation in lime-based mortars with added metakaolin, portland cement and sepiolite, for grouting of historic masonry" Cem. Concr. Res. 40 (1): 66-76. https://doi.org/10.1016/j.cemconres.2009.08.028.

Silva, B., A. E. Pigouni, M. R. Valluzzi, and C. Modena. 2014. "Calibration of analytical formulations predicting compressive strength in consolidated three-leaf masonry walls" Constr. Build. Mater. 64: 28-38. https://doi.org/10.1016/j.conbuildmat.2014.04.044.

Silva, R. 2008. "Experimental characterization of masonry: Strengthening and long term effects." [In Portuguese.] Master thesis, Dept. of Civil Engineering, Univ. of Minho.

Toumbakari, E. 2002. "Lime-pozzolan-cement grouts and their structural effects on composite masonry walls." Ph.D. thesis, Dept. of Civil Engineering, Katholieke Universiteit Leuven.

Valluzi, M. 2000. "Comportamento Meccanico di Murature Consolidate Con Materiali e Tecniche a Base di Calce." Tesi de Dottorato, Dept. of Cultural Heritage, Universita Degli Studi di Trieste.

Valluzi, M., F. da Porto, and C. Modena. 2001. "Behaviour of multi-leaf stone masonry walls strengthened by different intervention techniques." In Proc., Historical Constructions, edited by P. B. Lourenço, and P. Roca. Panaji, India: Fundação Oriente.

Valluzzi, M. R., F. Da Porto, and C. Modena. 2004. "Behavior and modeling of strengthened three-leaf stone masonry walls" Mater. Struct. 37 (3): 184-192. https://doi.org/10.1007/BF02481618.

Vintzileou, E. 2006. "Grouting of three-leaf stone masonry: Types of grouts, mechanical properties of masonry before and after grouting." In Proc., Structural Analysis of Historical Constructions, edited by P. B. Lourenço, P. Roca, C. Modena, and S. Agrawal. Panaji, Goa, India: Fundação Oriente.

Vintzileou, E. 2007. "Iniezione di miscela fluida in muratura a sacco: Risultati sperimentali e previsione delle caratteristiche meccaniche." In Seminar CIAS Evoluzione nella sperimentazione per le costruzioni, 191-211. Merano: CIAS.

Vintzileou, E. 2011. "Three-leaf stone masonry in compression, before and after grouting: A review of literature" Int. J. Architect. Heritage 5 (4-5): 513-538. https://doi.org/10.1080/15583058.2011.557137.

Vintzileou, E., and A. Miltiadou-Fezans. 2008. "Mechanical properties of three-leaf stone masonry grouted with ternary or hydraulic lime-based grouts" Eng. Struct. 30 (8): 2265-2276. https://doi.org/10.1016/j .engstruct.2007.11.003.

Vintzileou, E., and T. Tassios. 1995. "Three-leaf stone masonry strengthened by injecting cement grouts" J. Struct. Eng. 121 (5): 848-856. https://doi.org/10.1061/(ASCE)0733-9445(1995)121:5(848). 